International Journal of Solar Thermal Vacuum Engineering

\title{
Daylighting, artificial electric lighting, solar heat gain, and space-heating energy performance analyses of electrochromic argon gas-filled smart windows retrofitted to the building
}

\author{
Saim Memon ${ }^{1 *}$, Robert Dawson ${ }^{1}$, Zafar Said $^{2,3}$, Siamak Hoseinzadeh ${ }^{4}$, Ali Sohani ${ }^{5}$, Ali Radwan ${ }^{6}$, \\ Takao Katsura ${ }^{7}$ \\ 1 Solar Thermal Vacuum Engineering Research Group, London Centre for Energy Engineering, School of Engineering, London South Bank \\ University, London, United Kingdom \\ 2 Department of Sustainable and Renewable Energy Engineering, University of Sharjah, P. O. Box 27272, Sharjah, United Arab Emirates \\ 3 U.S.-Pakistan Center for Advanced Studies in Energy (USPCAS-E), National University of Sciences and Technology (NUST), Islamabad, Pakistan \\ 4 Department of Planning, Design, Technology of Architecture, Sapienza University of Rome, Rome, Italy \\ 5 Laboratory of Optimization of Thermal Systems' Installations, Faculty of Mechanical Engineering-Energy Division, K.N. Toosi University of \\ Technology, Tehran, Iran \\ 6 Mechanical Power Engineering Department, Mansoura University, Egypt \\ 7 Division of Human Environmental Systems, Faculty of Engineering, Hokkaido University, N13-W8, Kita-ku, Sapporo 060-8628, Japan
}

\section{ABSTRACT}

The inevitability to reduce $\mathrm{CO}_{2}$ emissions to avoid preventable climate change is widely being yelped. To minimise the impact of rapidly changing climate, this paper presents novel research findings and contributes to developing electrochromic argon gas-filled glazed smart windows retrofitted to the building with loT based transparency control. In this, the comparative analyses of the daylighting, electrical lighting, solar heat gain, and space-heating load of the building using the dynamic thermal and electric lighting modelling methods based on real weather temperatures are presented. The daylighting analysis results implicate that the building with electrochromic argon gas-filled smart windows reduced $19 \%$ of daylight illuminance during summer months compared with the building retrofitted with double air-filled glazed windows daylight factor remains consistent. As such, the solar heat gains analysis results implicate at least $50 \%$ annual solar heat gain reduction predicted in the building with electrochromic argon gasfilled smart windows in comparison to double air-filled windows. This leads to the conclusion of the space-heating energy analysis that implicates the highest contribution to the space heating demand is the solar heat gain caused by double air-filled glazed windows. The results confirm that the LED artificial electric lighting system requires fewer fittings and thus total power load compared to the fluorescent lighting system, throughout the year, to the building with electrochromic argon gas-filled glazed smart windows. The daylight controls are linked to the electrochromic argon gas-filled glazed smart windows, so they only operate when the glazing is tinted, or the daylight level drops below a set level; this will reduce the energy usage and also lower the space heating of the room.

\section{Keywords:}

Electrochromic; Argon gas; Smart Windows; Daylighting; Artificial electric lighting, Solar Heat Gain; Energy Performance

\footnotetext{
* Corresponding author.

E-mail address: S.Memon@lsbu.ac.uk (S. Memon)
}

https://doi.org/10.37934/stve.3.1.5072 


\section{Introduction}

The inevitability to reduce $\mathrm{CO}_{2}$ emissions, in order to avoid preventable climate-change, is echoed by the IPCC sixth assessment report in 2021 [1] that states the earth warm up of $1.1^{\circ} \mathrm{C}$ since 1850 1900 caused by human activities and over the next 20 years, the global surface temperature would rise to at least $1.5^{\circ} \mathrm{C}$. In order to minimise the impact of rapidly changing climate, the domestic and residential buildings are of particular focus because of its considerable cooling energy loss in hot arid countries, such as in UAE/Egypt, and space-heating energy loss in cold-arid countries, such as in Japan/UK/EU [2,3]. This is because the solar radiation entering the room through the windows generates an unpredictable quantity of heat in the hot-arid climate or more globally during summer months [4-6]; however, the same windows also enable heat within the room to leave, necessitating the production of extra heat to maintain the needed temperature during winter months in the coldarid climate. A conventional double air-filled glazed windows are the most common type of windows retrofitted in the world, and while these provide moderate thermal resistance, they still allow much heat to transfer through the glazing; they also do not prevent direct daylight from entering the building, causing further heat gains [7]. Despite having several building stock insulation methods and improved heating \& cooling systems as retrofitting measures that are being researched [8], there is a cost-effective scope of minimising space-heating/cooling energy by incorporating progressive technologies such as electrochromic argon gas-filled smart windows. It consists of a thin electrochromic film and a thick layer of argon-gas between two sheets of glass. This has the potential to reduce the energy demand at an unprecedented level and enhance the building windows with consumer loT control of transparency of the windows.

An electrochromic film, which can control visible light transmittance and solar heat gain from a light source when a 1-2 V DC, enables chemical reaction, switching power is applied. An electrochromic film is a chemically designed film capable of changing its transparency by varying applied voltage to the film. The type of metal oxide material determines the thickness of the film on a substrate. Generally, it averages between $100 \mathrm{~nm}$ and $1500 \mathrm{~nm}$ [9]. For example, the most popular metal oxide $\mathrm{WO}_{3}$ has an average thickness of 400-700 nm depending on the design and target application. The state transition time is another essential characteristic. Different materials take different amount of time to change state (colour and transparency). However, the main factor that affects the transition time, despite the material's original properties, is the film thickness.

At $750 \mathrm{~nm}$ thickness for $\mathrm{WO}_{3}$, the light transmittance is below $10 \%$ for most of the light wavelengths, and at $400 \mathrm{~nm}$, the transmittance stays below $20 \%$, with blue and green colours (450$550 \mathrm{~nm}$ wavelengths) being the most transmitted [10]. Sputtering, evaporation, and chemical vapour deposition are most commonly used to fabricate $400 \mathrm{~nm} \mathrm{WO}$ thin films [11]. Working pressure is significant for electrochromic films as they are fragile to damage. Most of the electrochromic devices have electrochromic films located between a substrate and another material. In windows, a metal oxide would be applied on indium tin oxide (ITO) coated glass and covered by another glass. The pressure between the glasses is important to maintain the efficient functioning of the electrochromic film. The working pressure can vary between 0.8-2 Pa for most metal oxides [9]. Finally, most metal oxide films would require $\mathrm{O}_{2}$ access; hence, the electrochromic glazing should not be completely sealed. 
Heavy gases such as Argon ( $\mathrm{Ar}$ ), Krypton ( $\mathrm{Kr}$ ), or Xenon (Xe) in a space between two glass sheets with a rim seal improves thermal performance compared to double air-filled glazing because heavy gases have lower thermal conductivity than air [12]. The thermal performance of Xenon or Krypton is better than argon gas because the density of Xenon and Krypton gas is greater than argon gas. Krypton gas has less density than Xenon gas, but both of these are expensive. One serious problem with rim seals is that as they are not perfectly leak-tight, part of the filling gas may diffuse out, and air could diffuse into the space, resulting in a deterioration of the thermal performance [13]. Glazings with cavities filled with different gases improve thermal performance (from 3.5 to $1.4 \mathrm{Wm}^{-2} \mathrm{~K}^{-1}$ ) depends on the cavity thickness. The predicted best thermal performance of the Xenon gas filled double glazing at the cavity width of $20 \mathrm{~mm}$ to be $1.4 \mathrm{Wm}^{-2} \mathrm{~K}^{-1}$ compared to other gas filled glazings. Predictions made by Heath et al. (2010) [14] showed that the air and argon gas filled double glazing could have the same center-of-pane $U$ value $\left(1.8 \mathrm{Wm}^{-2} \mathrm{~K}^{-1}\right)$ at different cavity widths (10 mm for argon gas filled double glazing and $15 \mathrm{~mm}$ for air filled glazing). The minimum centre-of-pane $U$ value can be achieved at the cavity width of $20 \mathrm{~mm}$ in double air-filled glazing down to $1.8 \mathrm{Wm}^{-2} \mathrm{~K}^{-1}$. The optimum cavity width with Krypton gas filled double glazing is considered to be around $10 \mathrm{~mm}$ and for Xenon around $7 \mathrm{~mm}$. The centre-of-pane $U$ value of these gas filled glazing units cannot be reduced to below $1 \mathrm{Wm}^{-2} \mathrm{~K}^{-1}$ [15]. With vacuum glazing, the thermal transmission centre-of-pane $U$ value can be reduced to $0.8 \mathrm{Wm}^{-2} \mathrm{~K}^{-1}$ and triple vacuum glazing to $0.8 \mathrm{Wm}^{-2} \mathrm{~K}^{-1}$ when evacuating the space between two low-e coated (e.g., tin-oxide coating $\varepsilon$ of 0.15 ) glass sheets $[16,17]$. A pressure of less than $0.1 \mathrm{~Pa}$ reduces gaseous conduction and convective heat transfer to at a negligible level (except heat conduction through support pillars, and edges), and radiation heat transfer can be reduced using soft low emittance coatings (e.g., silver coating $\varepsilon$ of 0.02) [18-20]. However, the fusion edge sealed vacuum glazing [21] and composite edge-sealed triple vacuum glazing [22-24], invented by Dr. Memon, are still in the progressive stages that might take years to achieve such technologies at the mass manufacturing level $[25,26]$. Indeed, the cost of vacuum insulation is one of the predominant factors, but the benefits of improved thermal and electrical efficiencies with the use of vacuum insulation on PV solar thermal collector $[27,28]$ and translucent vacuum insulation $[29,30]$ are meaningful. The solar thermal collectors on residential buildings also produce waste heat [31,32] that can be harnessed using thermoelectric [33-35], and with PV [36], the use of the water-cooling method is still attractive in the hot-arid humid climate. A new development in nanocomposites $[37,38]$ can improve vacuum sealed solar thermal collectors' performance. In the current need, the electric vehicles [39-41] and its development of the charging station integrated into a residential building with fast charging algorithms [42-44] are also being explored where thermal heat management of the batteries would be required.

The electrochromic film is the key to making windows ideal heat insulators, since vacuum glazing cannot tackle heat transmission through radiation without low-e coatings. The outer glass typically has an electrochromic film that can be used as a light deflector (absorber) by not letting some or all light pass through glass. Electrochromic argon gas-filled glazed smart windows can bring the average thermal insulation along with solar heat gain coefficient ( $G$-value) as a cost-effective solution. This can change the transparency to reduce the amount of daylight entering a building and increase thermal resistance. The amount of heat from daylight that enters the building through the window is expressed as a value between 0 and 1 and is referred to as the G-value, common double air-filled glazing has a G-value of around 0.6, whereas electrochromic argon-gas filled glazing could be as low as 0.1. By increasing the G-Value of glazing, the amount of daylight that will enter a room can be reduced; by doing this, the solar heat gain within a room will reduce. Solar heat gain is the term used for the effect of the radiation from the sun heating an internal room when sunlight enters the room 
through a window. The amount of solar heat gains a room will have will be dependent on the direction of the windows; south facing windows get more direct sunlight, so rooms with south facing windows will have a higher solar heat gain than other rooms in a building. At the same time, solar heat gain may be advantageous at some times, for example, to warm a cold room in winter. In the summer, this is undesirable as it will cause the room to overheat, and an increased amount of cooling would be required to maintain the rooms at a comfortable temperature, therefore increasing the electrical demand. By reducing the amount of daylight into a room to lower the heat gain causes a requirement for electric lighting to be used to achieve the required light levels to enable users to work; using electric lighting will also create heat in a room so detracts from the benefit of reducing the solar heat gain [45]. Stopping natural daylight from entering a building also has a negative impact on users as natural daylight can benefit a person's health.

For the first time, this paper presents novel research findings and contributes to the development of electrochromic argon gas-filled glazed smart windows with loT-based transparency control. In this, the comparative analyses of the daylighting, electrical lighting, solar heat gain, and space-heating load of a building, as a case-study in Oxfordshire, UK, using the dynamic thermal and electric lighting modelling methods based on real weather temperatures. It incorporates electrochromic argon-filled glazed windows in comparison to double air-filled glazed windows.

\section{Research Methodology}

\subsection{Physical Model}

The physical model of the building, located in Oxfordshire, UK, is an existing two-story office building, as shown in Fig. 1. In which, the ground floor has standard double air-filled glazed windows, while the first floor has angled roof lights, so the simulation results can be observed to see how the different window types affect the solar heat gain and energy performances. The building is also ' $T$ ' shaped, so it has offices with different orientations, so the effect of the orientation can also be observed in the results. 


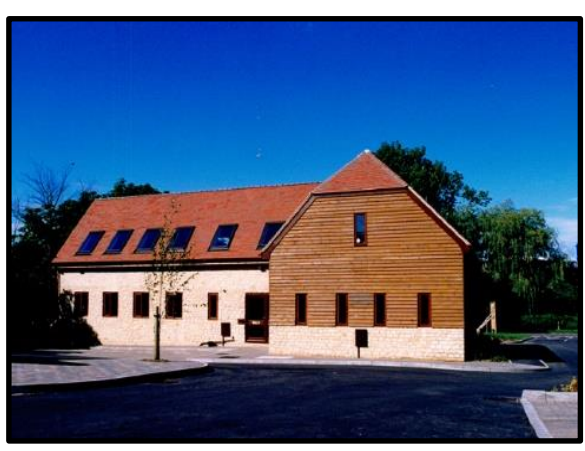

(a)

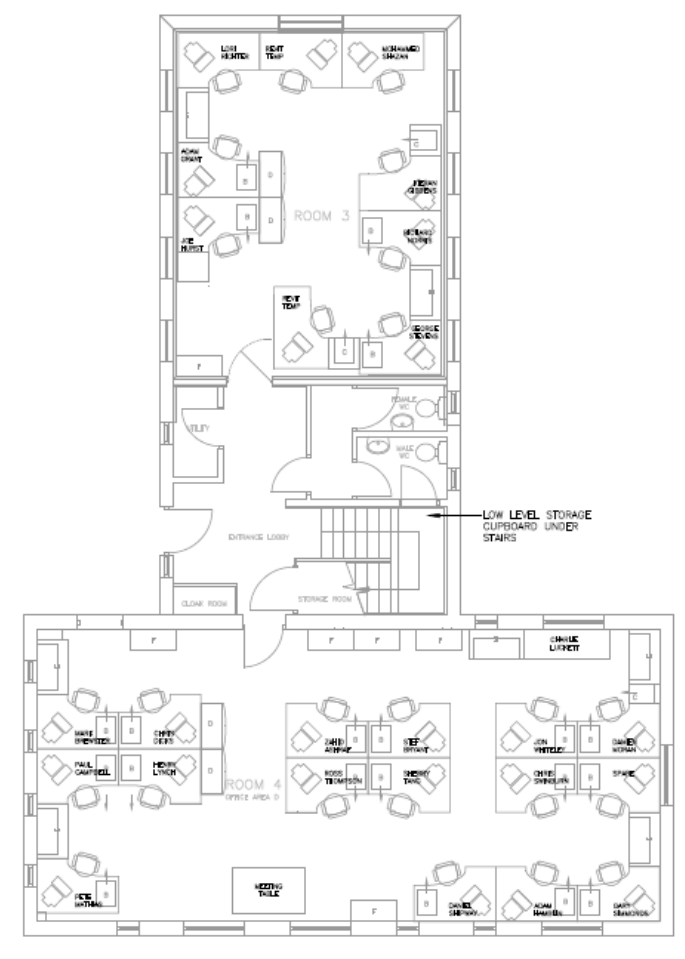

GROUND FLOOR

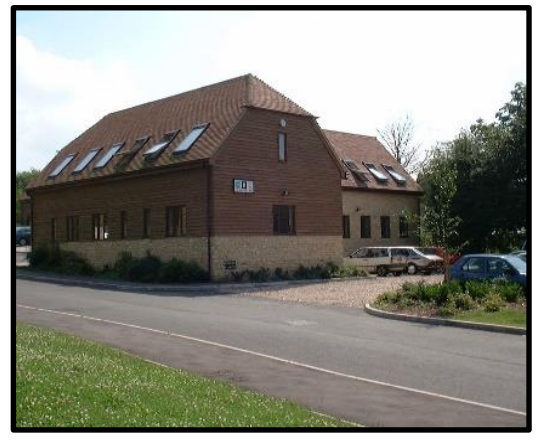

(b)

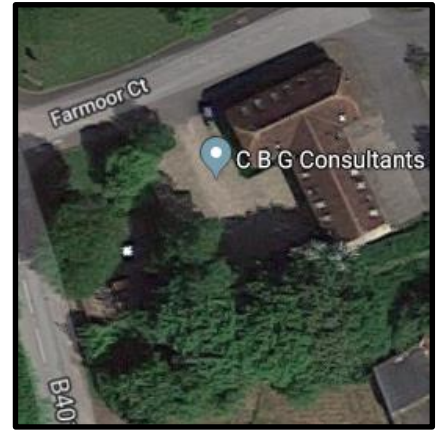

(c)

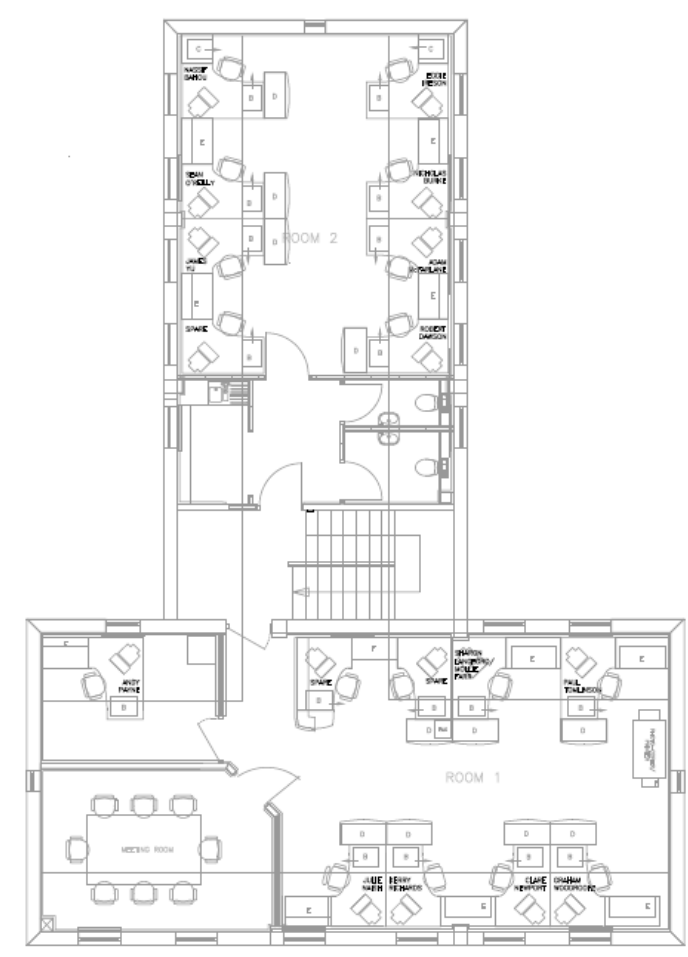

FIRST FLOOR

(d)

Fig. 1. The physical model of the building located in Oxfordshire, UK showing the (a) front view, (b) rear view, (c) top view, and (d) 2D AutoCAD floor plans of the physical model.

\subsection{D Building Model}

The 3D model of the designed building is shown in Fig. 2. The external doors were assumed to be glazed in construction to assess the extent of heat loss through double air-filled and electrochromic argon gas-filled windows. The front façade faced south. To accurately carry out calculations in the IES VE dynamic thermal modelling software, the geographical location of the building and its rotation are essential. A 1:1 scale of the area was taken from Google Earth and imported in SketchUp as an underlay and the building model was moved and rotated to sit in the correct location. With that done, the SketchUp model was completed and then imported to the IES VE. Although the geometry of the entire structure is included in the model, it is necessary to include shade from nearby objects when investigating daylighting. As a result, a study of the surrounding region was undertaken, and the model was updated to include the surrounding buildings and trees. 


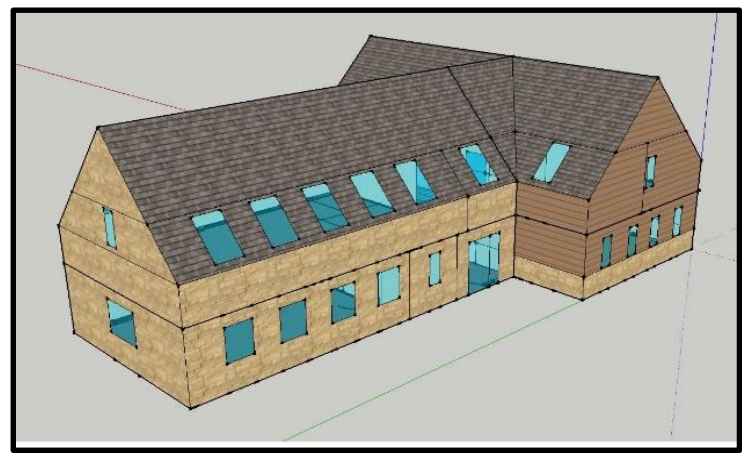

(a)

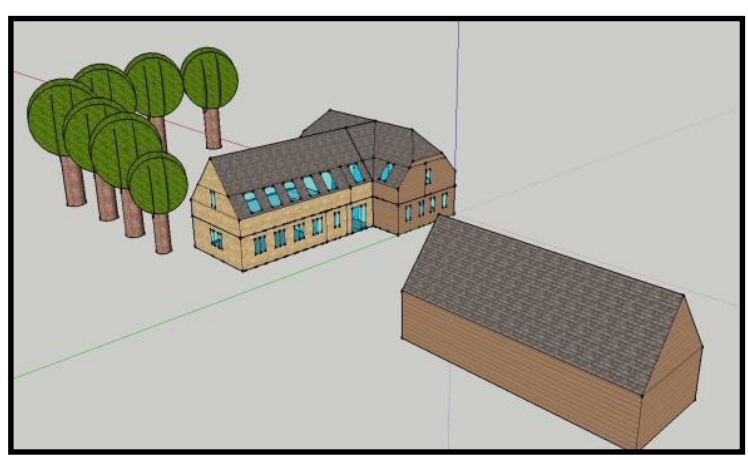

(c)

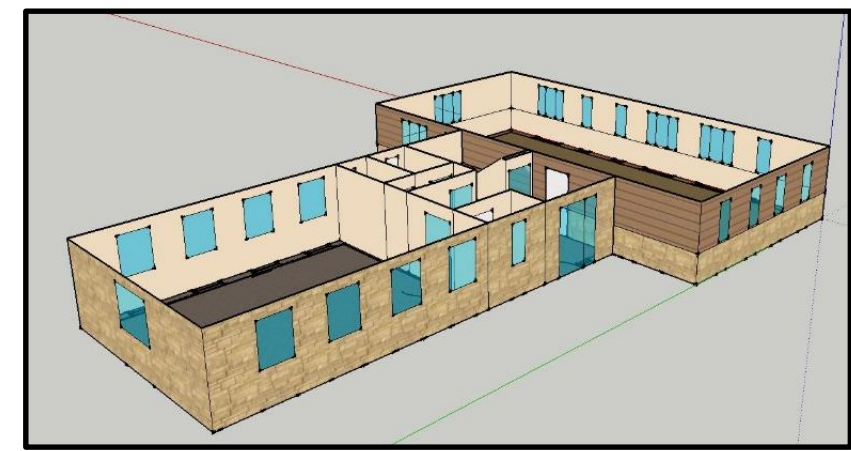

(b)

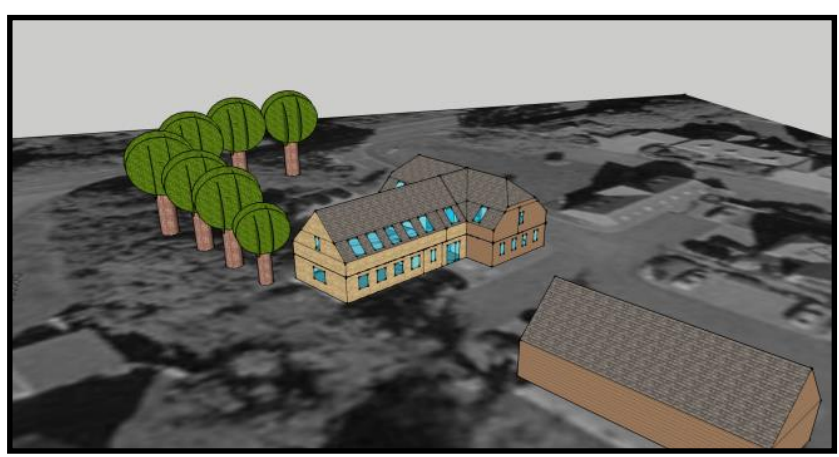

(d)

Fig. 2. A 3D model designed in Sketchup showing the (a) isometric view of the whole buildings, (b) crosssectional view of the ground floor, (c) incorporated external shading influence of trees, and (d) incorporated geographical location and climate of the whole building.

\subsection{Implemented Parameters to the Building Design and Simulation Method}

The Apache dynamic thermal simulation using IES VE is used to input details of the building into the model, which are required to carry out accurate calculations; full details of the modelling thermal methods are detailsed elsewhere [46-48]. The daylighting, solar heat gain, and space heating analyses with windows are focused on four office spaces for this building, two office spaces are on the ground floor, and two are on the first floor.

The Building Regulations Part $L$ contains rules on the maximum $U$-values permitted for new buildings. As the building being analysed was constructed around 1999, the materials used would have had to conform to the 1995 version of the Part L Building Regulations [49]; these figures can therefore be utilised for the building simulation and detailed in Table. 1. For this project, the parameters of the exiting double air-filled glazed windows are based on the 1995 edition of the Part L Building Regulations; this is because the building was constructed in 1999, so as a minimum, the values stated in 1995 Part $L$ regulations are implemented. The calculations are conducted as per CIBSE Guide A [50] and BS 10077-1 2006 [51] standard for the electrochromic argon-gas-filled glazed windows. 
Table 1.

The thermal transmittance ( $U$ values) implemented in the building designed model.

\begin{tabular}{ll}
\hline Building Component & $\mathbf{U}$ value $\left(\mathbf{W m}^{-2} \mathbf{K}^{-1}\right)$ \\
\hline Walls & 0.45 \\
Roof & 0.25 \\
Door & 3.0 \\
Internal Partitions & 1.97 \\
Ground & 0.63 \\
Double air-filled glazed window & 2.85 (G-value of 0.76) \\
Electrochromic argon gas-filled glazed & Clear 1.97 (G-value of 0.4) \\
window & \multicolumn{1}{c}{ Tinted 1.97 (G-value of 0.05) } \\
\hline
\end{tabular}

The internal heat gains by people and objects implemented in the dynamic simulation, as per CIBSE Guide $\mathrm{A}$, and are dependent on the usage of the electrical lighting devices and the level of physical work. A consideration of: $75 \mathrm{~W}$ for people seated and moderate work; $75 \mathrm{~W}$ sensible; $55 \mathrm{~W}$ latent gain; $135 \mathrm{~W}$ for desktop computers and monitors in these office spaces and; $400 \mathrm{~W}$ for photocopier are implemented.

In terms of the heating and cooling load requirements, the building has a gas-fuelled combi-boiler that serves radiators at $60{ }^{\circ} \mathrm{C}$ and hot water. The boiler has seasonal controls to allow the heating to be on at specific times; during the winter, the boiler is set to heat the building between 6 am and $1 \mathrm{pm}$, and during summer, between 8 am and $9 \mathrm{am}$. A thermostat determines the temperature the building is heated to during these times (for the purpose of this simulation, a temperature of $21{ }^{\circ} \mathrm{C}$ was used); outside these times, the temperature is set to be maintained at $12{ }^{\circ} \mathrm{C}$. A small ICT server room contains an air conditioning unit that is constantly on to keep the room below $21^{\circ} \mathrm{C}$.

The heating, ventilation, lighting, equipment, and occupancy profiles are implemented in the model of the building. The profiles were selected from templates within IES that are based on National Calculation Methodology (NCM) modelling guide [52] and are shown in Fig. 3. A control function was setup for the electrochromic argon gas-filled glazed windows so that the glazing remains clear while the room requires heating to allow solar gain; when the room reaches the heating set point of $21^{\circ}$ the electrochromic film will activate and begin to tint linearly between fully clear to fully shaded based on the solar irradiance. The IES VE uses dynamic weather data files created by CIBSE, containing information such as outside temperature, wind speed, and direction every hour for a typical year. The weather file used for this simulation is the Swindon TRY weather file. 


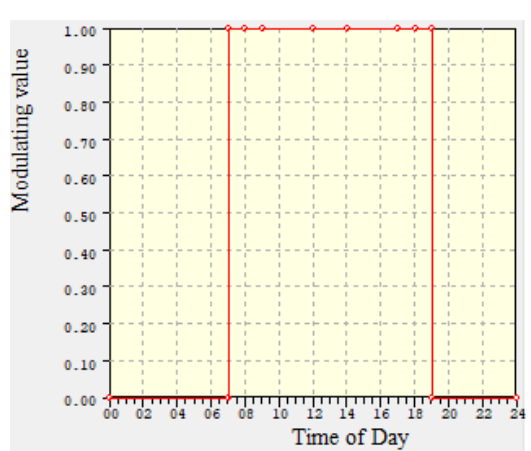

(a)

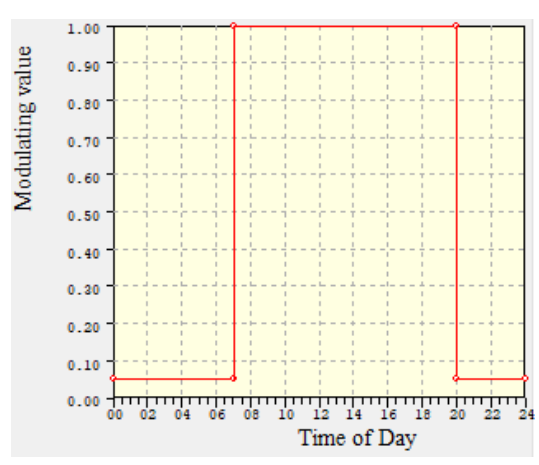

(d)

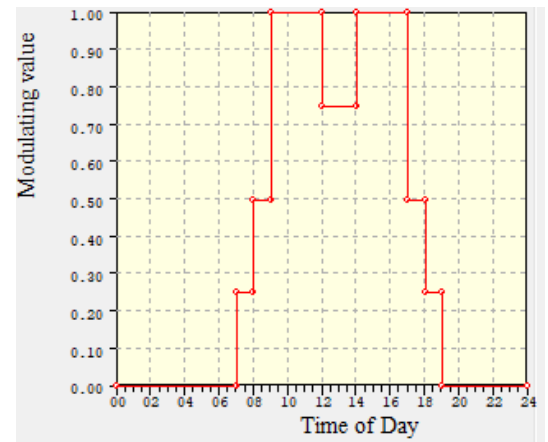

(b)

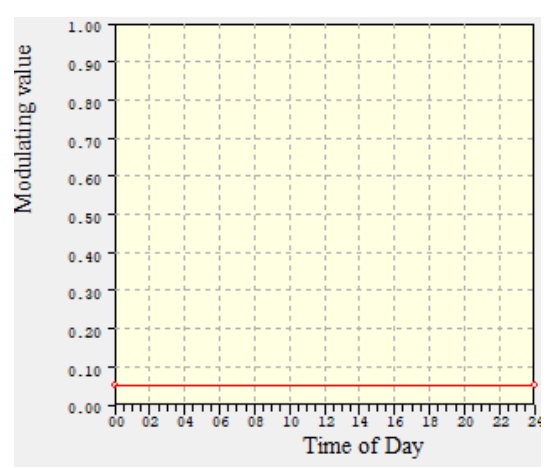

(e)

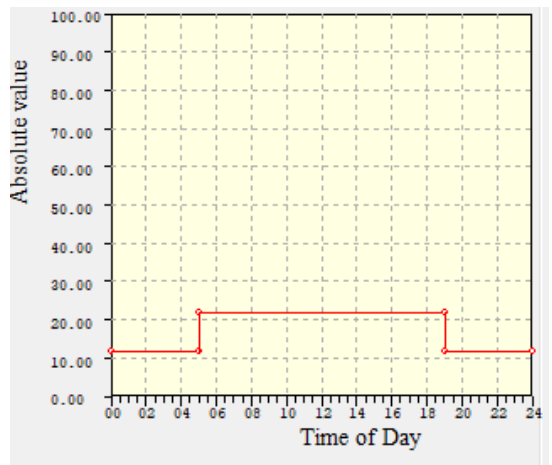

(g)

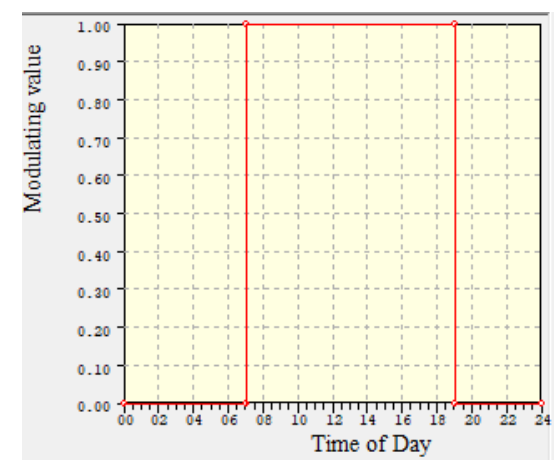

(c)

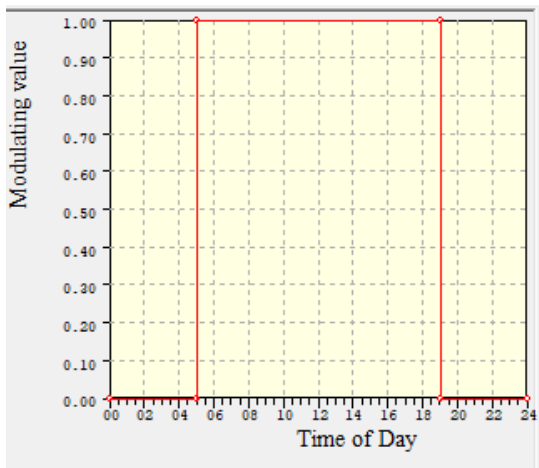

(f)

Fig. 3. (a) Ventilation profile showing ventilation running from 7 am to $7 \mathrm{pm}$, (b) Occupancy profile showing people start entering building at 07:00 and it ramps up until full occupancy at 09:00, drop between $12 \mathrm{pm}$ and $2 \mathrm{pm}$ as people leave for lunch and people start leaving at 17:00 until 19:00 when building is unoccupied, (c) lighting profile showing lighting running fully from 7 am to $7 \mathrm{pm}$, (d) equipment profile showing equipment running fully between $7 \mathrm{am}$ to $7 \mathrm{pm}$, outside this time $5 \%$ of equipment is running and (e) weekend profile for equipment running at $5 \%$, (f) cooling profile showing cooling running $100 \%$ between 5 am and $7 \mathrm{pm}$ when the temperature reaches above $21^{\circ} \mathrm{C},(\mathrm{g})$ heating profile showing heating running when the temperature drops below the threshold between 5 am and $7 \mathrm{pm}$ whilst maintain $12{ }^{\circ} \mathrm{C}$ throughout. 


\section{Results and discussion}

\subsection{Daylighting analysis}

Simulations were run for the building with double air-filled glazed windows and electrochromic argon gas-filled smart windows to determine the amount of daylight that is let through the glazing into the room; this was carried out for each of the four rooms being analysed and carried out during the summer period and the winter period. The simulation was carried out using FlucsDL and the measurements taken on the horizontal plane of the room with a $0.5 \mathrm{~m}$ border. The method that FlucsDL uses to determine the daylight factor within a room examines the amount of daylight for a set time and date and displays the results rather than simulating it over some time. For this reason, the date selected for the summer period analysis was July $15^{\text {th }}$ at midday; for the winter period, Jan $15^{\text {th }}$ at midday was used.

Table 2 shows the daylighting results for the building with double air-filled glazed windows. It can be seen from the results that during the winter period, the illuminance within each room is reduced, but the daylight factor remains consistent.

\section{Table 2.}

The daylighting illuminance and factor for the summer and winter periods for the building with double airfilled glazed windows.

\begin{tabular}{|l|l|c|c|c|}
\hline Summer Period & Min. & Ave. & Max. \\
\hline \multirow{2}{*}{ Room 1 } & Daylight factor & $0.8 \%$ & $8.1 \%$ & $22.4 \%$ \\
\cline { 2 - 5 } & Daylight illuminance & 136.27 lux & 1319.05 lux & 3650.88 lux \\
\hline \multirow{2}{*}{ Room 2 } & Daylight factor & $6.0 \%$ & $12.7 \%$ & $25.1 \%$ \\
\cline { 2 - 5 } & Daylight illuminance & 975.42 lux & 2076.08 lux & 4097.51 lux \\
\hline \multirow{2}{*}{ Room 3 } & Daylight factor & $1.8 \%$ & $4.9 \%$ & $12.9 \%$ \\
\cline { 2 - 5 } & Daylight illuminance & 290.75 lux & 793.76 lux & 2107.61 lux \\
\hline \multirow{2}{*}{ Room 4 } & Daylight factor & $0.5 \%$ & $2.8 \%$ & $13 \%$ \\
\cline { 2 - 5 } & Daylight illuminance & 88.56 lux & 459.79 lux & 2124.03 lux \\
\hline \multirow{2}{*}{ Winter Peom 1 } & Daylight factor & Min. & Ave. & Max. \\
\cline { 2 - 5 } & Daylight illuminance & 43.82 lux & 461.82 lux & 1280.50 lux \\
\hline \multirow{2}{*}{ Room 2 } & Daylight factor & $5.9 \%$ & $12.7 \%$ & $25.1 \%$ \\
\cline { 2 - 5 } & Daylight illuminance & 338.53 lux & 726.74 lux & 1436.59 lux \\
\hline \multirow{2}{*}{ Room 3 } & Daylight factor & $1.7 \%$ & $4.9 \%$ & $12.9 \%$ \\
\cline { 2 - 5 } & Daylight illuminance & 99.66 lux & 278.27 lux & 738.44 lux \\
\hline \multirow{2}{*}{ Room 4 } & Daylight factor & $0.5 \%$ & $2.8 \%$ & $13 \%$ \\
\cline { 2 - 5 } & Daylight illuminance & 28.21 lux & 160.93 lux & 744.94 lux \\
\hline
\end{tabular}

Table 3 showed the daylighting analysis when the electrochromic argon-gas-filled glazed smart windows are retrofitted to the building. The illuminance in the winter season is reduced, but the daylight factor is stable, similar to the daylight simulation done with the double air-filled glass windows. The illuminance levels and the daylight factor are lower when using the electrochromic argon gas-filled glazed smart windows, which is to be expected as this has a lower transmittance value than the double-glazed windows. As shown in Table 3, the illuminance control contributes to the decrease of daylighting, particularly during the summer months. 


\section{Table 3.}

The daylighting illuminance and factor for the summer and winter periods for the building with electrochromic argon gas-filled smart windows.

\begin{tabular}{|l|l|c|c|c|}
\hline \multicolumn{2}{|l|}{ Summer Period } & Min. & Ave. & Max. \\
\hline \multirow{2}{*}{ Room 1 } & Daylight factor & $0.7 \%$ & $6.4 \%$ & $17.7 \%$ \\
\cline { 2 - 5 } & Daylight illuminance & 117.33 lux & 1047.30 lux & 2885.22 lux \\
\hline \multirow{2}{*}{ Room 2 } & Daylight factor & $4.8 \%$ & $10.1 \%$ & $19.9 \%$ \\
\cline { 2 - 5 } & Daylight illuminance & 781.72 lux & 1652.15 lux & 3244.67 lux \\
\hline \multirow{2}{*}{ Room 3 } & Daylight factor & $1.4 \%$ & $3.9 \%$ & $10.3 \%$ \\
\cline { 2 - 5 } & Daylight illuminance & 235.28 lux & 635.03 lux & 1678.70 lux \\
\hline \multirow{2}{*}{ Woom 4 } & Daylight factor & $0.4 \%$ & $2.3 \%$ & $10.3 \%$ \\
\cline { 2 - 5 } & Daylight illuminance & 72.28 lux & 372.95 lux & 1678.61 lux \\
\hline \multirow{2}{*}{ Room 1 } & Daylight factor & Min. & Ave. & Max. \\
\cline { 2 - 5 } & Daylight illuminance & 39.10 lux & 365.75 lux & 1012.68 lux \\
\hline \multirow{2}{*}{ Room 2 } & Daylight factor & $4.7 \%$ & $10.1 \%$ & $19.9 \%$ \\
\cline { 2 - 5 } & Daylight illuminance & 270.87 lux & 577.77 lux & 1137.15 lux \\
\hline \multirow{2}{*}{ Room 3 } & Daylight factor & $1.4 \%$ & $3.9 \%$ & $10.3 \%$ \\
\cline { 2 - 5 } & Daylight illuminance & 79.03 lux & 221.04 lux & 587.57 lux \\
\hline \multirow{2}{*}{ Room 4 } & Daylight factor & $0.3 \%$ & $2.2 \%$ & $10.2 \%$ \\
\cline { 2 - 5 } & Daylight illuminance & 20.02 lux & $127.50 \%$ & 586.07 lux \\
\hline
\end{tabular}

\subsection{Solar heat gains analysis}

A solar heat gain simulation was run in the IES VE using SunCast and Apache to calculate how much heat enters the building through the windows [53]. The simulation is run throughout the entire year, as well as the winter and summer months.

Fig. 1 shows the annual solar heat gain analysis comparing the building of double air-filled glazed windows with electrochromic argon gas-filled smart windows for Room 1, Room 2, Room 3, and Room 4. The results indicate that the building retrofitted with electrochromic argon gas-filled smart windows achieved a higher reduction in overall for all rooms. However, it was noticed that Room 4 received the least solar heat gains compared to other rooms due to the location of Room 4 not facing south.

Table 4 shows a maximum of $68.3 \%$ reduction of annual solar heat gains with electrochromic argon gas-filled smart windows achieved in the Room 1 . This is due to the fact of installation of electrochromic argon-gas filled smart windows to angled roof lights that provide a slightly better reduction than on vertical windows in other rooms. Overall, at least $50 \%$ annual solar heat gain reduction was predicted in the building with electrochromic argon gas-filled smart windows compared to double air-filled windows. 


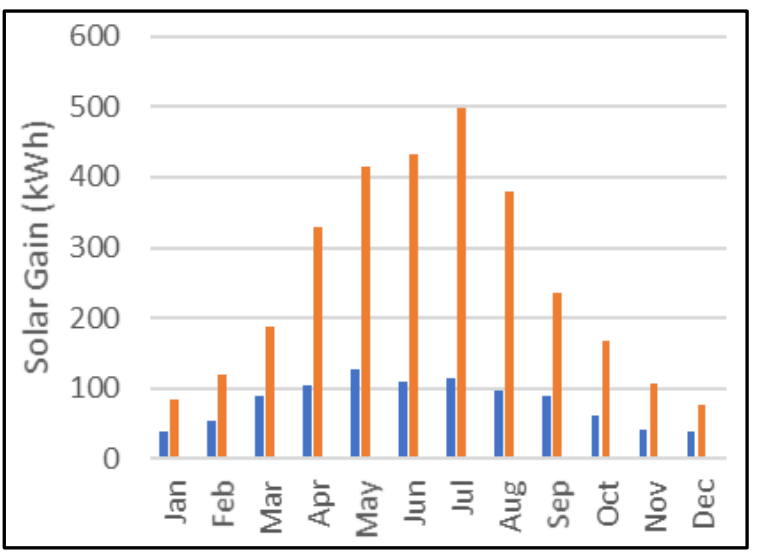

(a) Room 1

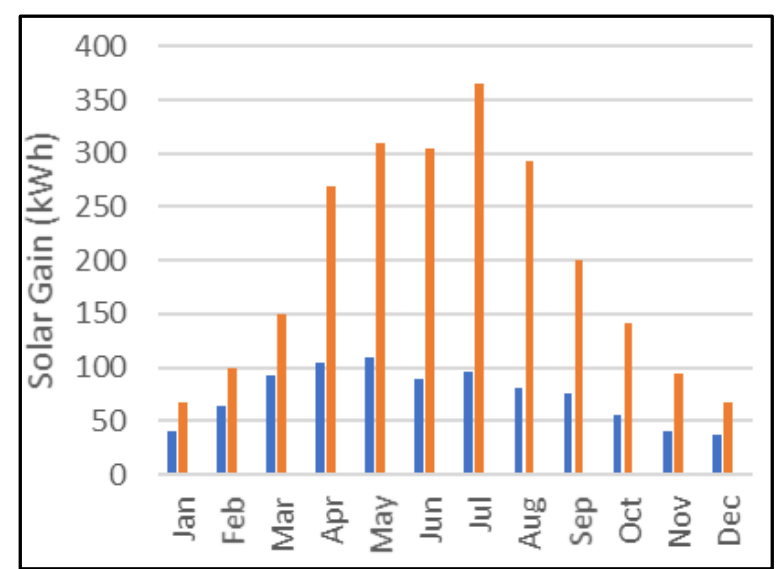

(c) Room 3

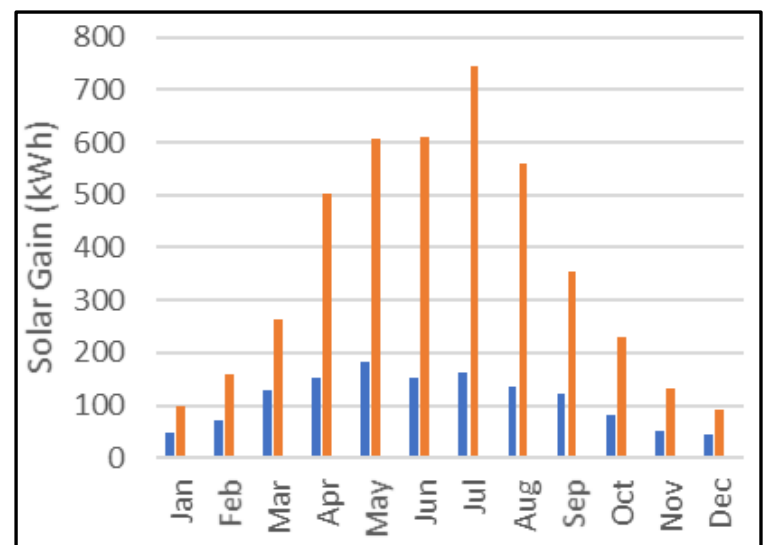

(b) Room 2

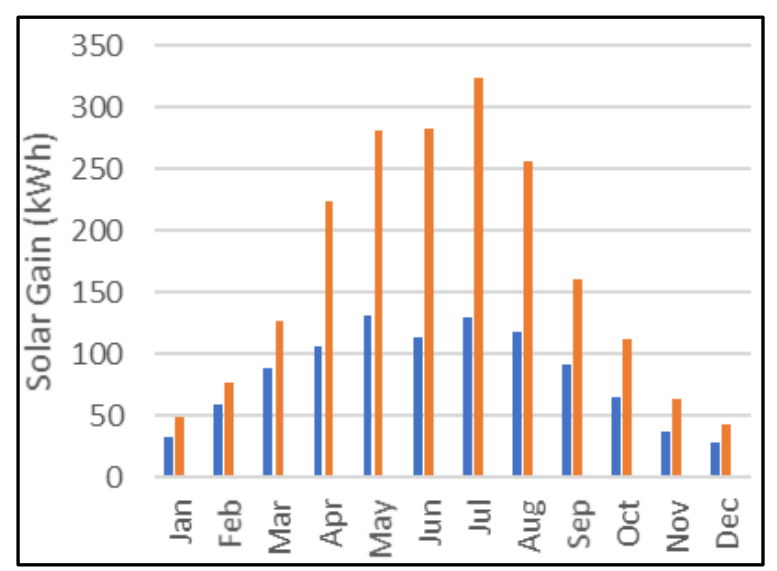

(d) Room 4

Building with Double Air-filled Glazed Windows

Building with Electrochromic Argon Gas-filled Smart Windows

Fig. 4. Annual solar heat gain analysis comparing the building of double air-filled glazed windows with electrochromic argon gas-filled smart windows for (a) Room 1, (b) Room 2, (c) Room 3 and, (d) Room 4 of the simulated building.

Table 4.

The total annual solar heat gain for four rooms of the simulated building is retrofitted with electrochromic argon gas-filled glazed windows compared to double air-filled glazed windows.

\begin{tabular}{lcccc}
\hline Building with & Room 1 & Room 2 & Room 3 & Room 4 \\
\hline Double air-filled glazed windows & $3032.4 \mathrm{kWh}$ & $4355.4 \mathrm{kWh}$ & 2359.5 kWh & 2002 kWh \\
\hline Electrochromic argon gas-filled glazed windows & $961.5 \mathrm{kWh}$ & $1339.9 \mathrm{kWh}$ & $889 \mathrm{kWh}$ & $1002.2 \mathrm{kWh}$ \\
\hline $\begin{array}{l}\text { Annual reduction of solar heat gains with } \\
\text { electrochromic argon gas-filled glazed windows }\end{array}$ & $68.3 \%$ & $69.2 \%$ & $62.3 \%$ & $50 \%$ \\
\hline
\end{tabular}

It is pertinent to precisely distinguish the performance of the building with double air-filled windows with electrochromic argon-gas-filled windows for summer months and winter months separately. As with the control-to-consumers of electrochromic switching characteristics with loT [54], it is possible to tint during summer months when unwanted solar heat gains can increase discomfort and cooling energy requirement. For this, Fig. 5 shows the solar heat gain analysis comparing the building of double air-filled glazed windows with electrochromic argon gas-filled smart windows for the summer months and winter months. Fig. 5a indicates a higher reduction of 
solar heat gains during the summer months than winter months, as shown in Fig. 5b, with electrochromic argon gas-filled smart windows.

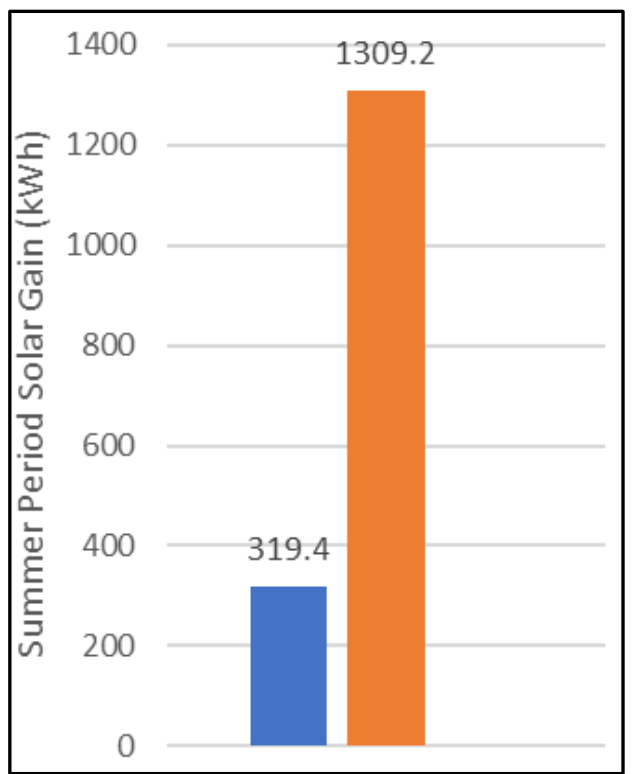

(a)

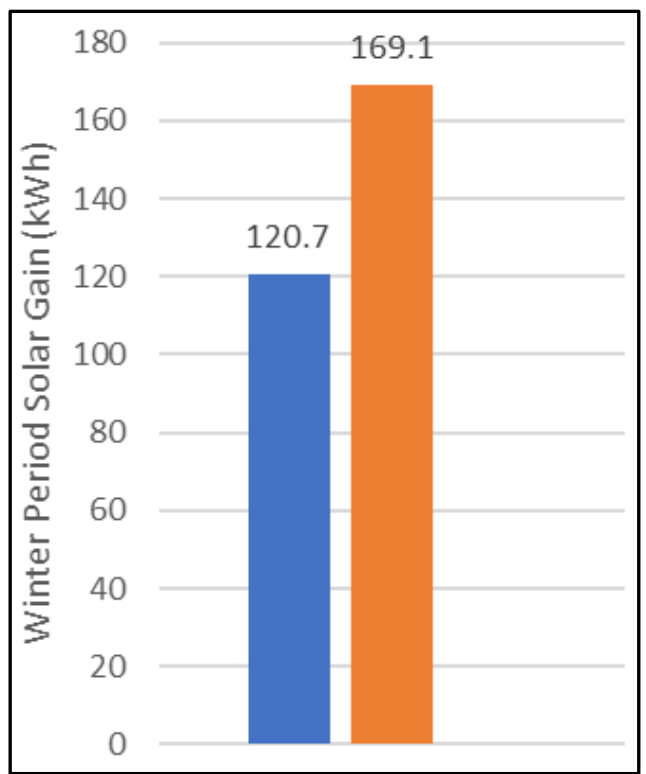

(b)

Building with Double Air-filled Glazed Windows

Building with Electrochromic Argon Gas-filled Smart Windows

Fig. 5. Solar heat gain analysis comparing the building of double air-filled glazed windows with electrochromic argon gas-filled smart windows for (a) summer months and, (b) winter months.

Table 5.

The total summer and winter months solar heat gain for four rooms of the simulated building retrofitted with electrochromic argon gas-filled glazed windows compared to double air-filled glazed windows.

\begin{tabular}{|c|c|c|c|c|c|}
\hline Time Period & Building with & Room 1 & Room 2 & Room 3 & Room 4 \\
\hline \multirow{5}{*}{$\begin{array}{l}\text { Summer } \\
\text { Months }\end{array}$} & Double air-filled glazed windows & 1309.2 & 1911.6 & $962 \mathrm{kWh}$ & 863.7 \\
\hline & & $\mathrm{kWh}$ & kWh & & kWh \\
\hline & Electrochromic argon gas-filled glazed windows & 319.4 & 453.1 & 266.5 & 361 \\
\hline & & kWh & kWh & kWh & kWh \\
\hline & $\begin{array}{l}\text { Reduction of solar heat gains with electrochromic } \\
\text { argon gas-filled glazed windows }\end{array}$ & $75.6 \%$ & $76.3 \%$ & $72.3 \%$ & $58.2 \%$ \\
\hline \multirow{5}{*}{$\begin{array}{l}\text { Winter } \\
\text { Months }\end{array}$} & Double air-filled glazed windows & 278.9 & 348.2 & $234 \mathrm{kWh}$ & 169.1 \\
\hline & & kWh & kWh & & kWh \\
\hline & Electrochromic argon gas-filled glazed windows & 130.3 & 165.1 & 142.2 & 120.7 \\
\hline & & kWh & kWh & kWh & kWh \\
\hline & $\begin{array}{l}\text { Reduction of solar heat gains with electrochromic } \\
\text { argon gas-filled glazed windows }\end{array}$ & $53.3 \%$ & $52.6 \%$ & $39.2 \%$ & $28.6 \%$ \\
\hline
\end{tabular}

Table 5 shows the total summer and winter months solar heat gain for four rooms of the simulated building retrofitted with electrochromic argon gas-filled glazed windows compared to double air-filled glazed windows. In which, at least 58\% reduction of solar heat gains was found during summer months compared to $28 \%$ during winter months. The room's location and orientation to the south are important factors. However, the thermal stress on the glazing itself, such as vacuum 
glazing, is reported elsewhere [55,56]. In this, during the summer months, Room 1 has the most significant decrease of $75.6 \%$ solar heat gains, compared to $53.3 \%$ during the winter months. The above findings are all based on the electrochromic film's automated control feature linked to profiles and sun path; thus, they were taken at different levels of transparency for comparison.

To understand the influence of different levels of transparency of electrochromic argon gas-filled smart windows, Fig. 6 shows the dynamic solar heat gain analysis at varying electrochromic argon gas-filled smart windows in comparison to double air-filled glazed windows of the building. From these results, it can be seen that even when the electrochromic film is off so the glazing is fully clear that the solar gain is lower than that of the building with double air-filled glazed windows due to the improved characteristics of the electrochromic film, as it does minimise the heat transfer through radiation that can be said as improved low-emittance coating. When the electrochromic film is tinted, it reduces the solar gain linearly between the fully clear and fully tinted states; the automatic control function for the glazing appears to be maintaining the tint at around $50 \%$ with an increase to around $75 \%$ in the summer months.

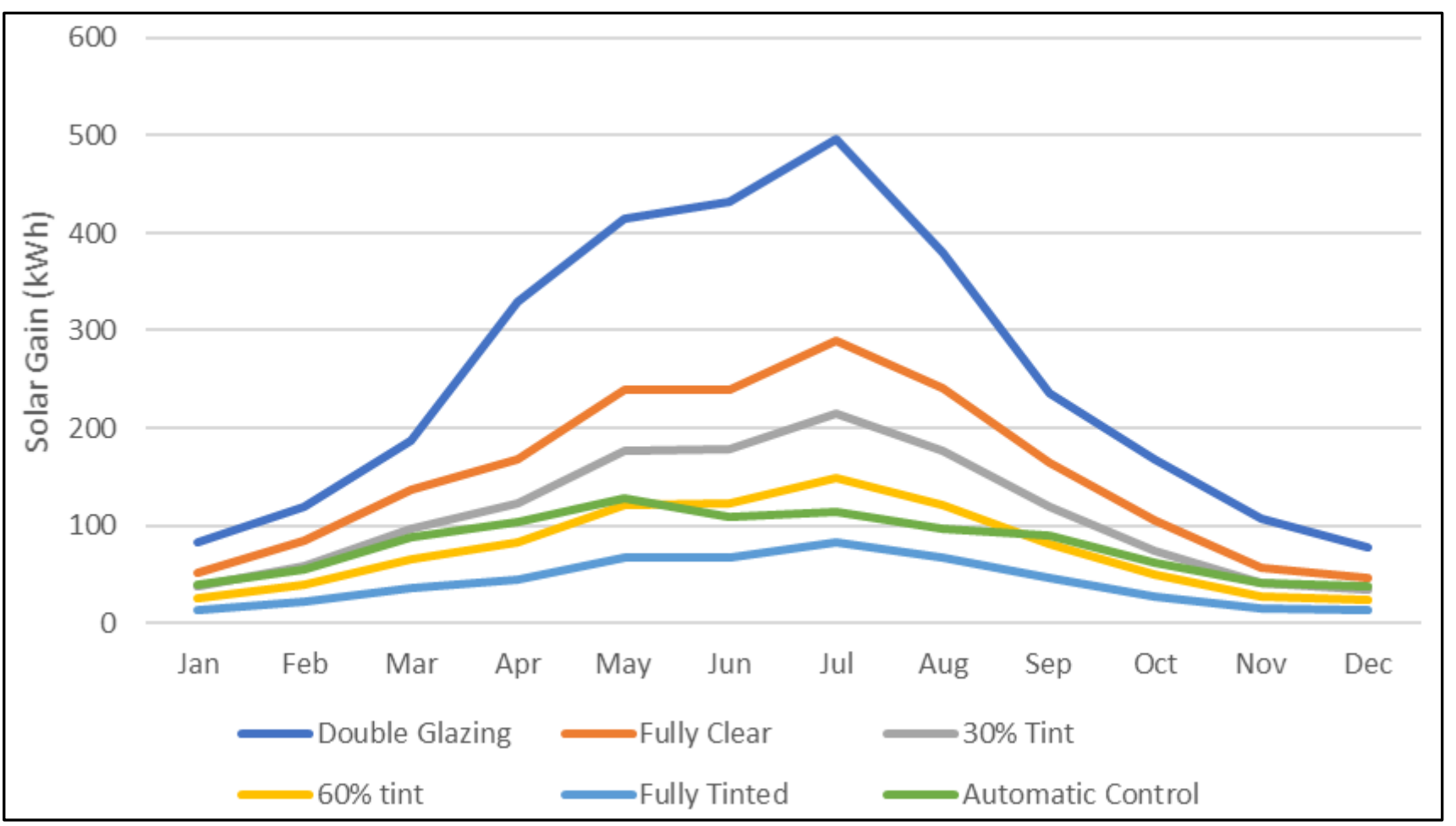

Fig. 6. Dynamic Solar heat gains analysis at varying electrochromic argon gas-filled smart windows compared to double air-filled glazed windows of the building. 


\subsection{Space-heating and energy gains analysis}

In this section, the amount of heat that enters the building from the outside through the windows and building fabric, the amount of heat generated within the building from sources such as occupants, computers, lighting, heating sources (radiators, etc.), and finally the amount of heat that leaves the building through the windows and building fabric are all parameters for Room 1 presented in Fig. 7 and Fig. 8. The space heating simulation was run for one year; this yearly simulation uses the profiles, as shown in Fig. 3, to control the operation of the heating, cooling, vent, and lighting to accurately determine how much heat is being created from each element. The results for Room 1 for a reason understood that has the greater influence of daylighting as discussed in section 3.2. Fig. 7 shows that the highest contribution to the space heating (heat plant sensible load) is the solar heat gain caused by the use of double air-filled glazed windows retrofitted to the building. On the other hand, Fig. 8 shows a significant reduction of space heating resulting from electrochromic argon gasfilled glazed windows. By comparing Fig. 7 and Fig. 8, the results imply that the solar heat gains within room 1 reduce, and the external conduction gain is also improved. The results for the summer months show almost similar space heating energy requirements. The results for the winter months show that the building with double air-filled glazed windows requires less than $50 \%$ of space heating compared to the building with electrochromic argon-gas-filled glazed windows, which is a trade-off. However, the internal energy gains with the room 1 are the combination of Infiltration, equipment, lighting, people, and conduction gains through the fabric remain consistent when compared Fig. 7, which shows the building with double air-filled glazed windows, with Fig. 8, that shows the building with electrochromic argon gas-filled glazed smart windows.

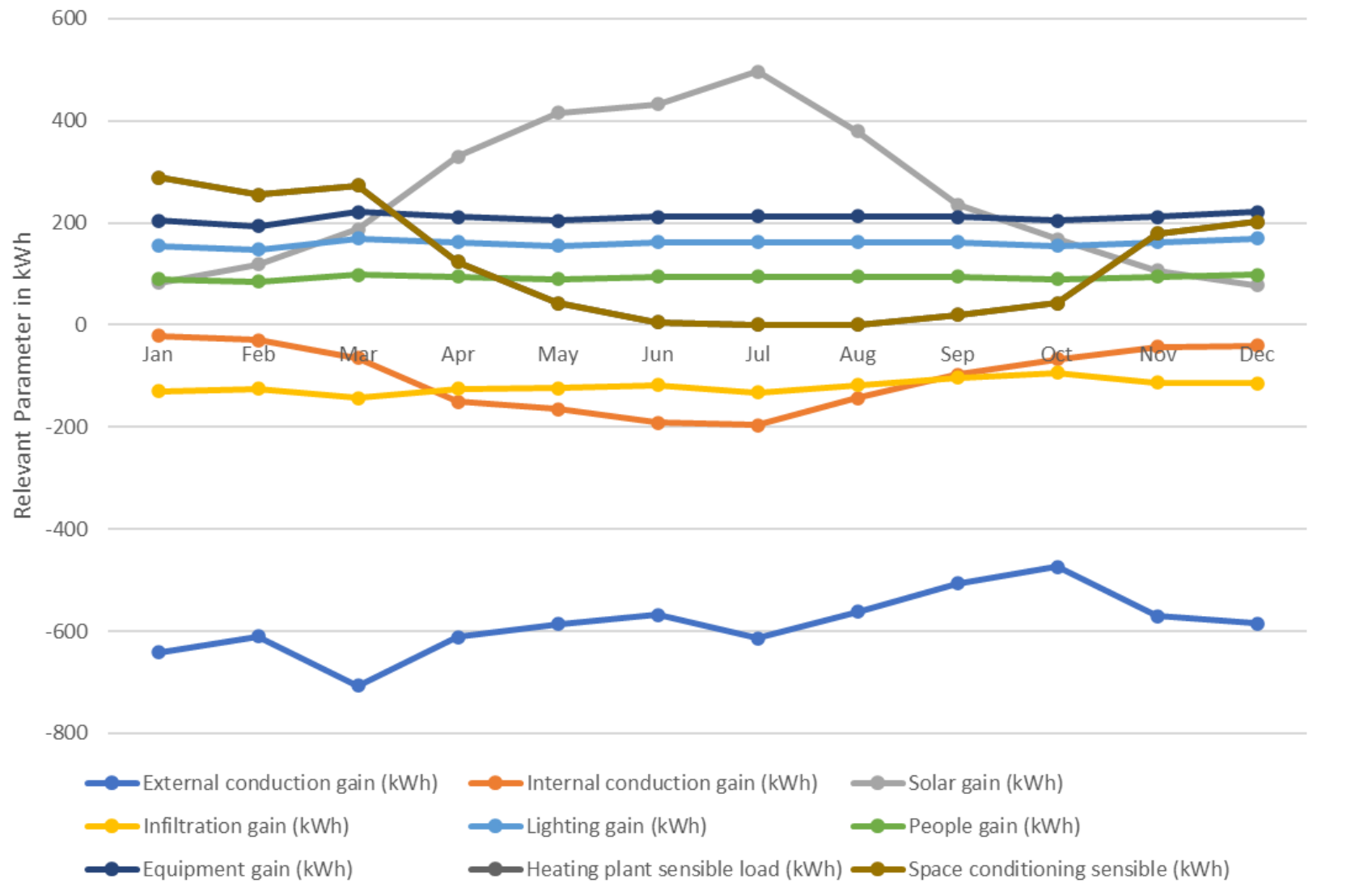

Fig. 7. Annual months space heating and various energy gains analysis for the Room 1 of the building with double air-filled glazed windows. 


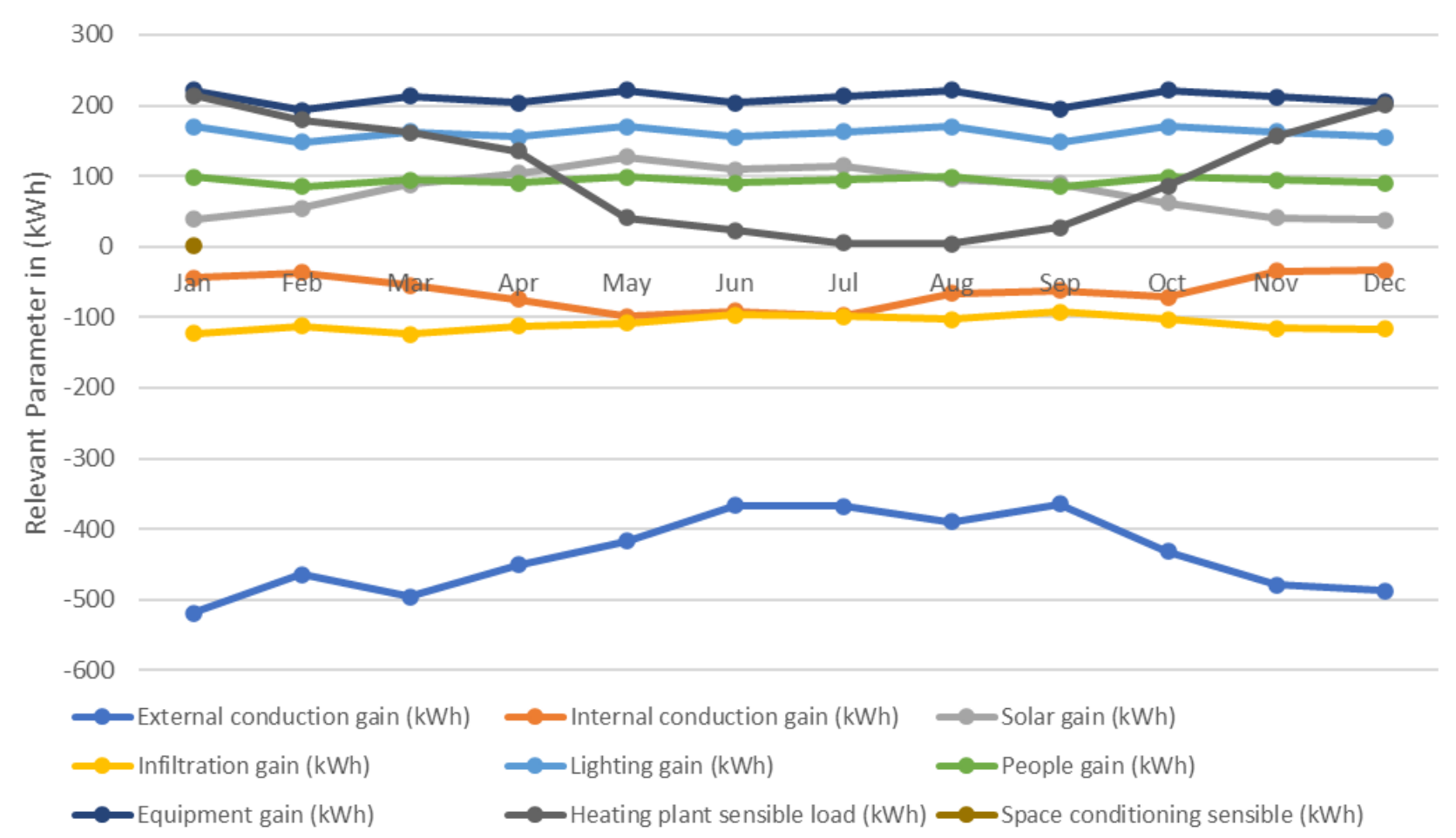

Fig. 8. Annual months space heating and various energy gains analysis for the Room 1 of the building with electrochromic argon gas-filled smart windows.

\subsection{Artificial electric lighting energy analysis}

As one of the variables that contribute to space heating, it was got to examine LED lighting to fluorescent lighting in a modelled building with a reference Room 2 to determine if it impacts the building's heat gain. Artificial electric lighting within a building needs to be carefully considered to achieve the required lux levels within various standards. The requirements for lighting levels can be found in CIBSE lighting guides [57], the SLL Code for Lighting [58], and British Standard BS EN 124641:2011 [59]. The CIBSE lighting guides are split into sections LGO - LG17 and cover the requirements for different buildings; the lighting guide applies to office buildings in Lighting Guide 07: Offices [60]. By using energy efficient electric lighting, the number of luminaires required to meet the requirement of the standards can be reduced; this will create several benefits, including reducing the amount of energy required to light a room and lowering the heat gain within the room. [61]. Various electric lighting technologies have been used as artificial lighting, each with advantages and disadvantages; the two familiar sources of lighting systems utilised nowadays are fluorescent and LED.

LED lights are more energy efficient than fluorescent, so they have the potential to save energy, and they also do not radiate heat into the room, so they can serve to reduce thermal heat gains with the building [62]. To enable these analyses to be investigated, a lighting design will need to be carried out to determine how many lights are required to comply with the British Standards and CIBSE Lighting guides. To carry out the lighting calculations, Relux Desktop is utilised; this has been chosen as it is also highly recognised in the industry as a suitable program for lighting design, and all the major lighting manufacturer's data is incorporated into the software, finding a suitable light fitting easier. The 2D AutoCAD drawing of the building, as shown in Fig. 1, was imported in Relux and used to create the 3D space of the offices that are being used, as shown in Fig. 9. 


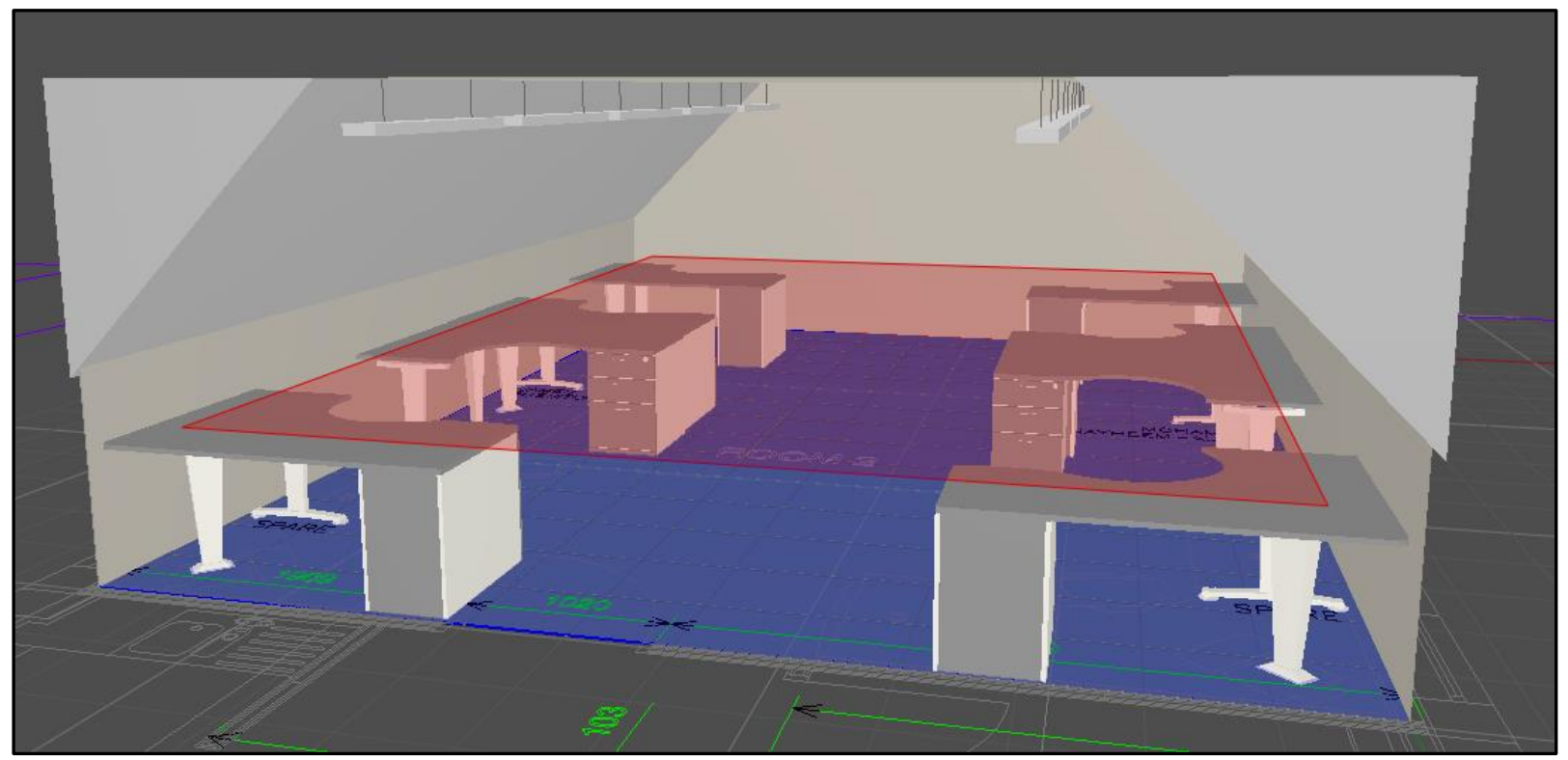

Fig. 9. 3D artificial lighting analysis of the modelled Room 2 with reference plane at desk height.

The room 2 lighting details are added; this included setting the reflectance values for the walls, ceiling, and floor; the default values relux added were $70 \%$ for the walls, 50\% for the ceiling, and $20 \%$ for the floor. From a survey of the office, these values seemed reasonable and were kept. The measuring area was then set; as this is an office, the area requiring lighting will be the desks, so the measuring area was set at $0.75 \mathrm{~m}$. The British Standard BS EN 12464-1 [59] and CIBSE Lighting Guide 7 [60] were reviewed to establish the required lighting level for an office space. From this, it was found that for these offices 500 lux would be required.

According to BS EN 12464-1 [59], the glare rating cannot exceed 19; this was considered when selecting a light fitting for the offices. Suitable light fittings were chosen for the office spaces; the ground floor offices contained a $600 \times 600$ ceiling grid, so a recessed modular fitting with an appropriate diffuser was chosen to comply with the glare rating. The first floor offices have a plasterboard ceiling, so a suspended linear fitting with a suitable diffuser was chosen. A fluorescent tube fitting and an LED fitting was chosen for each type of fitting.

With the light fittings selected and the required lux level determined, the calculation was carried out to determine the number of lights required for each office. The built-in EasyLUX feature of relux was used for this, as shown in Fig. 10. The type of light proposed for the space is selected, the maintenance value is then added; the default value for this is 0.8 and was left at this figure, the mounting of the light fitting is then chosen, and the required lux entered. Once the information is entered, the program calculated how many light fittings are required to achieve those conditions within the building. 


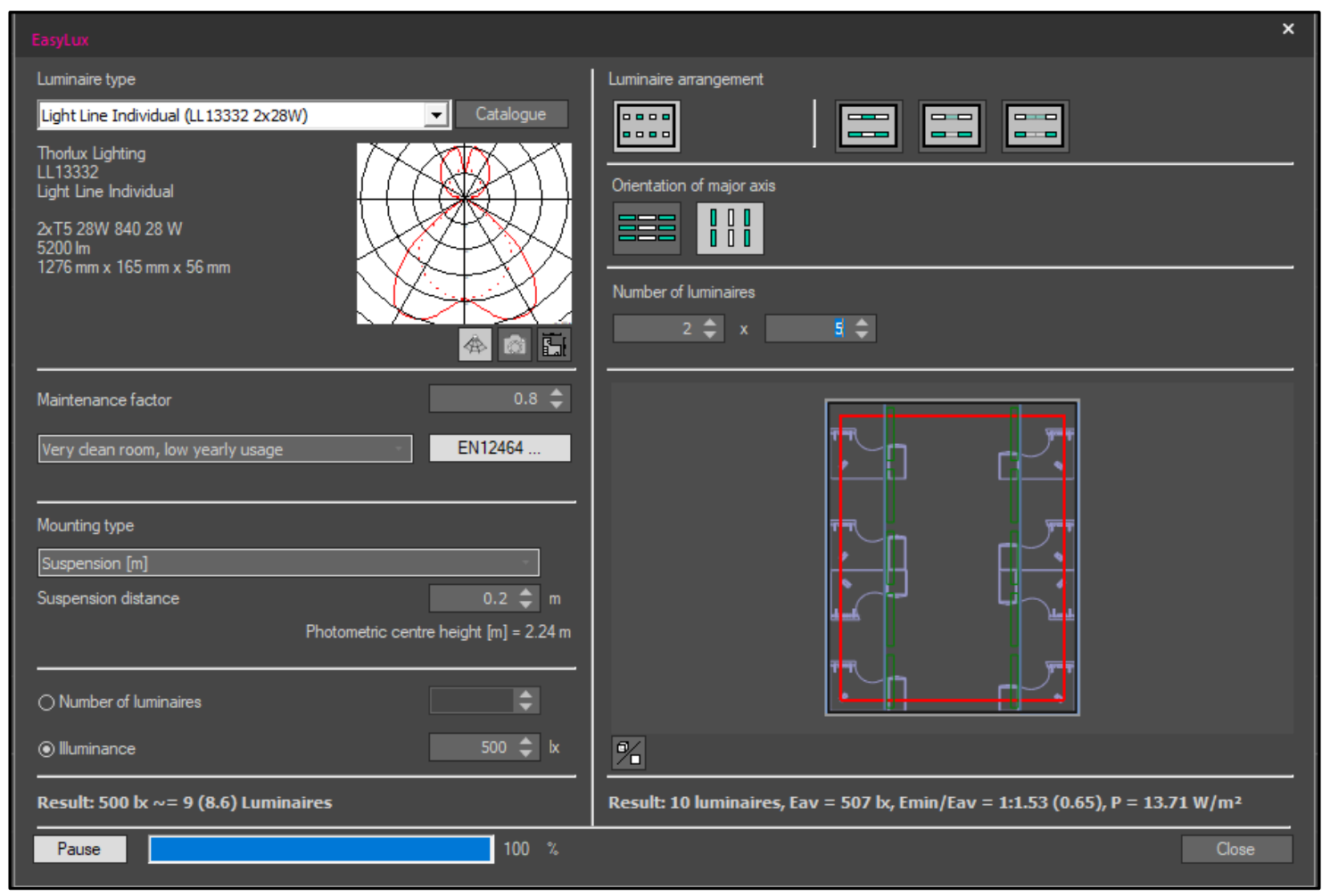

Fig. 10. The Easylux feature of relux implemented for lighting luminaires calculations of the modelled building with electrochromic argon gas-filled glazed smart windows.

The results from the calculations are shown in Table 6. It shows that the LED lighting system requires a lower number of fittings and thus total power load compared to the fluorescent lighting system.

\section{Table 6.}

The results of comparing the fluorescent lighting with LED lighting and required total power for all rooms of the building with electrochromic argon gas-filled glazed windows.

\begin{tabular}{|l|l|l|l|}
\hline \multicolumn{5}{|c|}{ Fluorescent Lighting } \\
\hline Room & Number of Fittings & Calculated Lux Level & Total Power \\
\hline Room 1 & 11 & 530 lux & 671 Watts \\
\hline Room 2 & 10 & 507 lux & 610 Watts \\
\hline Room 3 & 12 & 583 lux & 540 Watts \\
\hline Room 4 & 20 & 522 lux & 900 Watts \\
\hline \multicolumn{5}{|c|}{ LED Lighting } \\
\hline Room 1 & 7 & 607 lux & 441 Watts \\
\hline Room 2 & 6 & 486 lux & 318 Watts \\
\hline Room 3 & 9 & 592 lux & 297 Watts \\
\hline Room 4 & 16 & 548 lux & 528 Watts \\
\hline
\end{tabular}

The LED lighting specifications were entered into IES VE modelled building with electrochromic argon gas-filled glazed windows. The simulation was conducted to evaluate the illumination gain of fluorescent compared to the LED lighting system implemented based on the calculations above. 


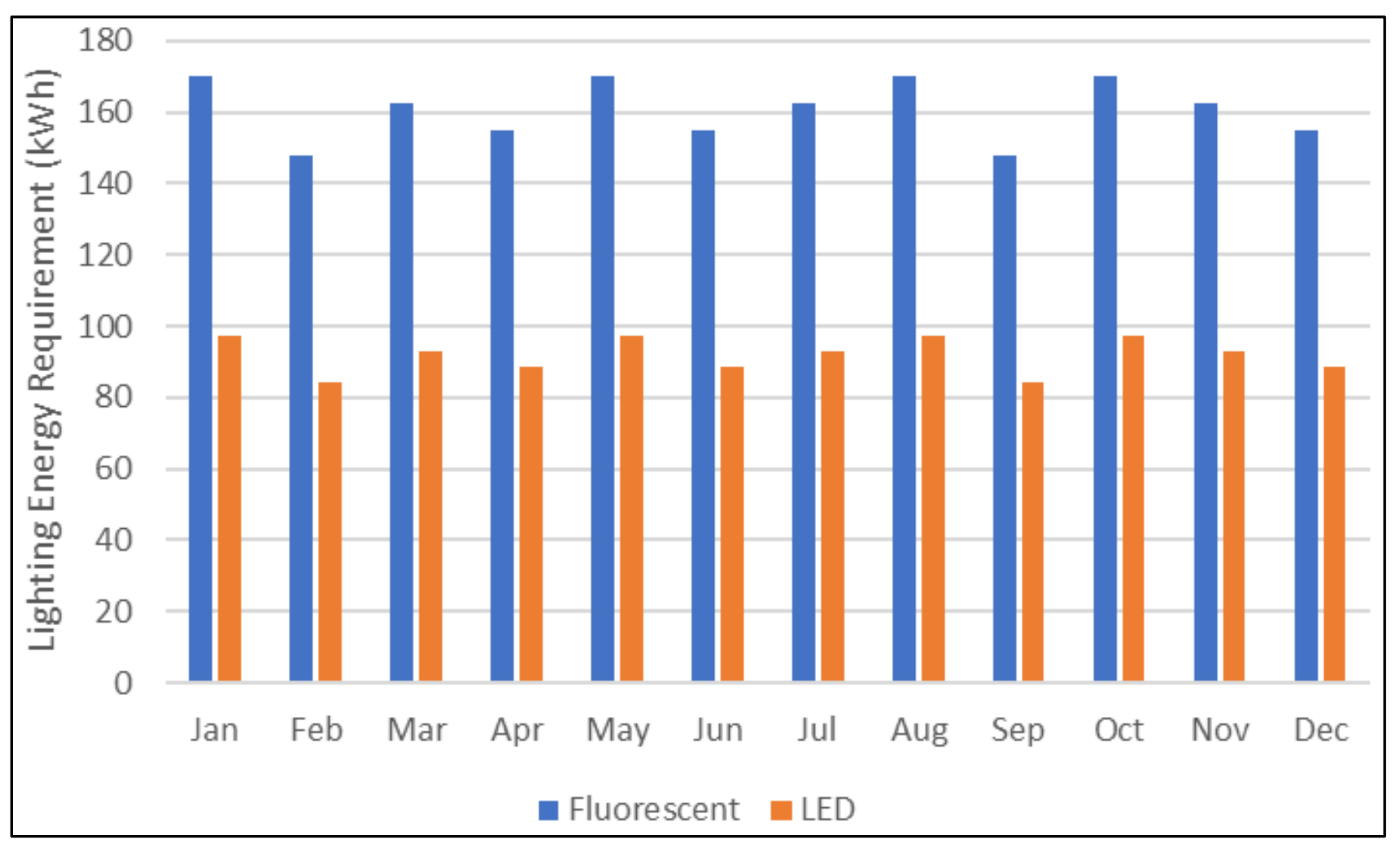

Fig. 11. Annual artificial lighting energy requirement analysis compares the LED lighting with fluorescent lighting systems implemented in the building with electrochromic argon gas-filled glazed smart windows showing the LED lighting requires a much lesser amount of power throughout the year.

Fig. 11 shows the artificial lighting power requirement with LEDs is much lower than the fluorescent luminaires, so by using these and having them setup with daylight controls linked to the electrochromic argon gas-filled glazed smart windows. Hence, they only operate when the glazing is tinted, or the daylight level drops below a set level; this will reduce the energy usage and lower the room's space heating.

\section{Conclusions}

To minimise the impact of rapidly changing climate, this paper presents the comparative analyses of the daylighting, artificial electric lighting, solar heat gain and space-heating energy performance of the building with a new electrochromic argon gas-filled glazed smart windows retrofitted to the building, as a case-study in Oxfordshire, UK, using the dynamic thermal and electric lighting modelling methods with real weather temperatures. The following five features summarise the key conclusions:

(i) The daylighting analysis results imply that the building with double air-filled glazed windows can achieve a higher daylight illuminance of 1491 lux in the summer months and 510 lux during the winter months. When comparing to the building with electrochromic argon gasfilled smart windows, the daylight illuminance of 1207 lux in summer months and 409 lux in winter months. The daylight factor remains consistent when comparing the building with double air-filled glazed windows with electrochromic argon gas-filled smart windows. 
(ii) The solar heat gain analysis results implicate that at least $50 \%$ annual solar heat gain reduction was predicted in the building with electrochromic argon gas-filled smart windows compared to double air-filled windows. The maximum of $68.3 \%$ reduction of annual solar heat gains with electrochromic argon gas-filled smart windows achieved in the Room 1 . This is due to the fact of installation of electrochromic argon-gas filled smart windows to angled roof lights that provide a slightly better reduction than on vertical windows in other rooms. The total summer and winter months solar heat gain for four rooms of the simulated building retrofitted with electrochromic argon gas-filled glazed windows compared to double air-filled glazed windows show at least 58\% reduction of solar heat gains during summer months compared to $28 \%$ during winter months. The room's location and orientation to the south are important factors. For example, Room 1 has the largest decrease of $75.6 \%$ solar heat gains during the summer months, compared to $53.3 \%$ during the winter months.

(iii) The influence of the dynamic solar heat gains analysis at varying electrochromic argon gasfilled smart windows compared to double air-filled glazed windows of the building are analysed. The results implicate that when the electrochromic film is tinted it reduces the solar gain linearly between the fully clear and fully tinted states; the automatic control function for the glazing appears to be maintaining the tint at around 50\% with an increase to around $75 \%$ in the summer months.

(iv) The space-heating energy analysis results implicate that the highest contribution to the space heating (heat plant sensible load) is the solar heat gain caused by the use of double air-filled glazed windows retrofitted to the building. On the other hand, a significant reduction of space heating resulted from using electrochromic argon gas-filled glazed windows is concluded. However, the results for the summer months show almost similar space heating energy requirements in both types of windows. In the winter, the building with double air-filled glazed windows uses less than half the amount of space heating as the building with electrochromic argon-gas-filled glazed windows is a trade-off.

(v) The results of artificial electric lighting energy analysis implicate that the LED lighting system requires a lower number of fittings and thus total power load compared to the fluorescent lighting system. When incorporated into the building with electrochromic argon gas-filled glazed smart windows, the results confirmed that artificial lighting power requirement with LEDs is much lower than the fluorescent luminaires throughout a year for the building with electrochromic argon gas-filled smart windows. The daylight controls are linked to the electrochromic argon gas-filled glazed smart windows, so they only operate when the glazing is tinted, or the daylight level drops below a set level; this will reduce the energy usage and also lower the space heating of the room.

\section{Acknowledgment}

This research work is supported by the Solar Thermal Vacuum Engineering Research Group and the developed international collaboration. 


\section{References}

[1] IPCC, 2021: Climate Change 2021: The Physical Science Basis. Contribution of Working Group I to the Sixth Assessment Report of the Intergovernmental Panel on Climate Change [Masson-Delmotte, V., P. Zhai, A. Pirani, S. L. Connors, C. Péan, S. Berger, N. Caud, Y. Chen, L. Goldfarb, M. I. Gomis, M. Huang, K. Leitzell, E. Lonnoy, J. B. R. Matthews, T. K. Maycock, T. Waterfield, O. Yelekçi, R. Yu and B. Zhou (eds.)]. Cambridge University Press. In Press.

[2] Memon, S., T. Katsura, A. Radwan, S. Zhang, A. A. Serageldin, E. M. Abo-Zahhad, S. Sergey et al. "Modern eminence and concise critique of solar thermal energy and vacuum insulation technologies for sustainable lowcarbon infrastructure." International Journal of Solar Thermal Vacuum Engineering 1, no. 1 (2020): 52-71. ISSN online (2716-6953). https://doi.org/10.37934/stve.1.1.5271

[3] Razmjoo, Armin, Meysam Majidi Nezhad, Lisa Gakenia Kaigutha, Mousa Marzband, Seyedali Mirjalili, Mehdi Pazhoohesh, Saim Memon, Mehdi A. Ehyaei, and Giuseppe Piras. "Investigating Smart City Development Based on Green Buildings, Electrical Vehicles and Feasible Indicators." Sustainability 13, no. 14 (2021): 7808.

https://doi.org/10.3390/su13147808

[4] Bensafi, Mohammed, Houari Ameur, Noureddine Kaid, Siamak Hoseinzadeh, Saim Memon, and Davide Astiaso Garcia. "Thermophysics Analysis of Office Buildings with a Temperature-Humidity Coupling Strategy Under HotArid Climatic Conditions." International Journal of Thermophysics 42, no. 8 (2021): 1-20. https://doi.org/10.1007/s10765-021-02858-1

[5] Khan, Asif, and Saim Memon. "Effect of hot-arid climatic solar energy on monocrystalline photovoltaic performance in Pakistan." International Journal of Solar Thermal Vacuum Engineering 2, no. 1 (2020): 19-39. https://doi.org/10.37934/stve.2.1.1939

[6] Tjahjono, Tri, Mehdi Ali Ehyaei, Abolfazl Ahmadi, Siamak Hoseinzadeh, and Saim Memon. "Thermo-Economic Analysis on Integrated CO2, Organic Rankine Cycles, and NaClO Plant Using Liquefied Natural Gas." Energies 14 no. 10 (2021): 2849.

https://doi.org/10.3390/en14102849

[7] Zhang, Shanwen, Min Kong, Hong Miao, Saim Memon, Yanjun Zhang, and Sixing Liu. "Transient temperature and stress fields on bonding small glass pieces to solder glass by laser welding: Numerical modelling and experimental validation." Solar Energy 209 (2020): 350-362.

https://doi.org/10.1016/i.solener.2020.09.014

[8] Ahmed, Mostafa, Ali Radwan, Ahmed Serageldin, Saim Memon, Takao Katsura, and Katsunori Nagano. "Thermal Analysis of a New Sliding Smart Window Integrated with Vacuum Insulation, Photovoltaic, and Phase Change Material." Sustainability 12, no. 19 (2020): 7846.

https://doi.org/10.3390/su12197846

[9] Li, Chuan, J. H. Hsieh, T. Y. Su, and P. L. Wu. "Experimental study on property and electrochromic function of stacked WO3/Ta2O5/NiO films by sputtering." Thin Solid Films 660 (2018): 373-379. https://doi.org/10.1016/i.tsf.2018.06.041

[10] Au, Benedict Wen-Cheun, Kah-Yoong Chan, and Dietmar Knipp. "Effect of film thickness on electrochromic performance of sol-gel deposited tungsten oxide (WO3)." Optical Materials 94 (2019): 387-392.

https://doi.org/10.1016/j.optmat.2019.05.051

[11] Georg, Andreas, Anneke Georg, Wolfgang Graf, and Volker Wittwer. "Switchable windows with tungsten oxide." Vacuum 82, no. 7 (2008): 730-735.

https://doi.org/10.1016/j.vacuum.2007.10.020

[12] Memon, Saim. "Design, fabrication and performance analysis of vacuum glazing units fabricated with low and high temperature hermetic glass edge sealing materials." PhD diss., Loughborough University, 2013. https://dspace.lboro.ac.uk/2134/14562

[13] Graves, Ronald S., and Robert R. Zarr. "Insulation Materials: Testing and Applications, Third Volume." ASTM, 1997.

[14] Heath, N., P. H. Baker, and G. Menzies. "Slim-profile double glazing-thermal performance and embodied energy, Historic Scotland technical paper 9, technical conservation group, Historic Scotland." (2013).

[15] Manz, Heinrich. "On minimizing heat transport in architectural glazing." Renewable Energy 33, no. 1 (2008): 119128.

https://doi.org/10.1016/i.renene.2007.01.007

[16] Memon, Saim, Yueping Fang, Essam Mohamed Abo-Zahhad, O. Abdelrehim, Mohamed R. Elmarghany, Abdul Rashid Memon, Shanwen Zhang, and Amos Darko. "Factors influencing the performance parameters of vacuum 
glazed smart windows to net zero energy buildings." International Journal of Solar Thermal Vacuum Engineering 2, no. 1 (2020): 1-18.

https://doi.org/10.37934/stve.2.1.118

[17] Memon, Saim, Yueping Fang, and Philip C. Eames. "The influence of low-temperature surface induction on evacuation, pump-out hole sealing and thermal performance of composite edge-sealed vacuum insulated glazing." Renewable energy 135 (2019): 450-464. https://doi.org/10.1016/i.renene.2018.12.025

[18] Memon, Saim, and Philip C. Eames. "Solar energy gain and space-heating energy supply analyses for solid-wall dwelling retrofitted with the experimentally achievable U-value of novel triple vacuum glazing." Journal of Daylighting 4, no. 1 (2017): 15-25.

https://doi.org/10.15627/jd.2017.2

[19] Fang, Yueping, Saim Memon, Jingqing Peng, Mark Tyrer, and Tingzhen Ming. "Solar thermal performance of two innovative configurations of air-vacuum layered triple glazed windows." Renewable Energy 150 (2020): 167-175. https://doi.org/10.1016/j.renene.2019.12.115

[20] Memon, Saim, and Philip C. Eames. "Solar energy gain and space-heating energy supply analyses for solid-wall dwelling retrofitted with the experimentally achievable $U$-value of novel triple vacuum glazing." Journal of Daylighting 4, no. 1 (2017): 15-25.

https://doi.org/10.15627/jd.2017.2

[21] Memon, Saim, and Philip C. Eames. "Design and development of lead-free glass-metallic vacuum materials for the construction and thermal performance of smart fusion edge-sealed vacuum glazing." Energy and Buildings (2020): 110430.

https://doi.org/10.1016/i.enbuild.2020.110430

[22] Memon, Saim, Farukh Farukh, Philip C. Eames, and Vadim V. Silberschmidt. "A new low-temperature hermetic composite edge seal for the fabrication of triple vacuum glazing." Vacuum 120 (2015): 73-82.

https://doi.org/10.1016/i.vacuum.2015.06.024

[23] Memon, Saim, and Philip C. Eames. "Predicting the solar energy and space-heating energy performance for solidwall detached house retrofitted with the composite edge-sealed triple vacuum glazing." Energy Procedia 122 (2017): 565-570.

https://doi.org/10.1016/j.egypro.2017.07.419

[24] Memon, Saim, Farukh Farukh, and Karthikeyan Kandan. "Effect of cavity vacuum pressure diminution on thermal performance of triple vacuum glazing." Applied Sciences 8, no. 9 (2018): 1705.

https://doi.org/10.3390/app8091705

[25] Memon, Saim. "Experimental measurement of hermetic edge seal's thermal conductivity for the thermal transmittance prediction of triple vacuum glazing." Case studies in thermal engineering 10 (2017): 169-178. https://doi.org/10.1016/i.csite.2017.06.002

[26] Memon, Saim. "Thermal Conductivity Measurement of Vacuum Tight Dual-Edge Seal for the Thermal Performance Analysis of Triple Vacuum Glazing." Impact of Thermal Conductivity on Energy Technologies (2018): 133.

http://dx.doi.org/10.5772/intechopen.74255

[27] Radwan, Ali, Takao Katsura, Saim Memon, Essam M. Abo-Zahhad, O. Abdelrehim, Ahmed A. Serageldin, Mohamed R. Elmarghany, Asmaa Khater, and Katsunori Nagano. "Development of a new vacuum-based photovoltaic/thermal collector, and its thermal and exergy analyses." Sustainable Energy \& Fuels 4, no. 12 (2020): 6251-6273.

https://doi.org/10.1039/D0SE01102A

[28] Radwan, Ali, Takao Katsura, Saim Memon, Essam M. Abo-Zahhad, Ahmed A. Serageldin, and Katsunori Nagano. "Analysis of a vacuum-based photovoltaic thermal collector." Energy Reports 6 (2020): 236-242. https://doi.org/10.1016/j.egyr.2020.11.255

[29] Katsura, Takao, Saim Memon, Ali Radwan, Makoto Nakamura, and Katsunori Nagano. "Thermal performance analysis of a new structured-core translucent vacuum insulation panel in comparison to vacuum glazing: Experimental and theoretically validated analyses." Solar Energy 199 (2020): 326-346.

https://doi.org/10.1016/i.solener.2020.02.030

[30] Radwan, Ali, Takao Katsura, Saim Memon, Ahmed A. Serageldin, Makoto Nakamura, and Katsunori Nagano. "Thermal and electrical performances of semi-transparent photovoltaic glazing integrated with translucent vacuum insulation panel and vacuum glazing." Energy Conversion and Management 215 (2020): 112920. https://doi.org/10.1016/i.enconman.2020.112920

[31] Memon, Saim. "Advanced Thermoelectric Materials for Energy Harvesting Applications." .IntechOpen Publisher, London, ISBN: 978-1-78984-529-7, (2020). 
https://doi.org/10.5772/intechopen. 77430

[32] Memon, Saim, Olatunde Muisdeen Lawal, Sumair Ahmed Tariq, and Bilal Khalid. "Wave energy in the UK: Current scope, challenges and prognostications." International Journal of Solar Thermal Vacuum Engineering 2, no. 1 (2020): 59-78.

https://doi.org/10.37934/stve.2.1.4058

[33] Memon, Saim, Maekele Mihreteab, Takao Katsura, Ali Radwan, Shanwen Zhang, Ahmed A. Serageldin, and Essam M. Abo-Zahhad. "Experimental and theoretical performance evaluation of parabolic trough mirror as solar thermal concentrator to thermoelectric generators." International Journal of Solar Thermal Vacuum Engineering 1, no. 1 (2020): 22-38. ISSN online (2716-6953).

https://doi.org/10.37934/stve.1.1.2238

[34] Memon, Saim, and Khawaja Noman Tahir. "Experimental and analytical simulation analyses on the electrical performance of thermoelectric generator modules for direct and concentrated quartz-halogen heat harvesting." Energies 11, no. 12 (2018): 3315.

https://doi.org/10.3390/en11123315

[35] Memon, Saim. "Introductory Chapter: Introduction to Advanced Thermoelectric Materials for Energy Harvesting Applications", Advanced Thermoelectric Materials for Energy Harvesting Applications, IntechOpen, London. (2019). https://doi.org/10.5772/intechopen.89640

[36] Sohani, Ali, Mohammad Hassan Shahverdian, Hoseyn Sayyaadi, Siamak Hoseinzadeh, Saim Memon, Giuseppe Piras, and Davide Astiaso Garcia. "Energy and Exergy Analyses on Seasonal Comparative Evaluation of Water Flow Cooling for Improving the Performance of Monocrystalline PV Module in Hot-Arid Climate." Sustainability 13, no. 11 (2021): 6084.

https://doi.org/10.3390/su13116084

[37] Memon, Saim, Gemeda Olani Nemera, and Tochukwu Israel Nwokeji. "Manifestations of carbon capture-storage and ambivalence of quantum-dot \& organic solar cells: An indispensable abridged review." International Journal of Solar Thermal Vacuum Engineering 2, no. 1 (2020): 40-58.

https://doi.org/10.37934/stve.2.1.4058

[38] Abo-Zahhad, Essam Mohamed, A. S. Hammad, Ali Radwan, Saim Memon, A. H. El-Shazly, and M. F. El-Kady. "Dye removal with magnetic graphene nanocomposite through micro reactors." International Journal of Solar Thermal Vacuum Engineering 2, no. 1 (2020): 79-94.

https://doi.org/10.37934/stve.2.1.7994

[39] Khan, Asif, Saim Memon, and T. P. Sattar. "Integration and management of solar energy for electric vehicle charging station." In Solar World Congress 2017-Innovation for the 100\% renewable energy transformation. Abu Dhabi, (2017). ISBN 978-3-981 465 9-7-6.

https://doi.org/10.18086/swc.2017.16.03

[40] Khan, Asif, Saim Memon, and Tariq Pervez Sattar. "Analyzing integrated renewable energy and smart-grid systems to improve voltage quality and harmonic distortion losses at electric-vehicle charging stations." IEEE Access 6 (2018): 26404-26415.

https://doi.ord/10.1109/ACCESS.2018.2830187

[41] Alayi, Reza, Farhad Zishan, Mahdi Mohkam, Siamak Hoseinzadeh, Saim Memon, and Davide Astiaso Garcia. "A Sustainable Energy Distribution Configuration for Microgrids Integrated to the National Grid Using Back-to-Back Converters in a Renewable Power System." Electronics 10, no. 15 (2021): 1826.

https://doi.org/10.3390/electronics10151826

[42] Makeen, Peter, Hani A. Ghali, and Saim Memon. "Experimental and Theoretical Analysis of the Fast Charging Polymer Lithium-Ion Battery Based on Cuckoo Optimization Algorithm (COA)." IEEE Access 8 (2020): 140486140496.

https://doi.org/10.1109/ACCESS.2020.3012913

[43] Makeen, Peter, Saim Memon, M. A. Elkasrawy, Sameh O. Abdullatif, and Hani A. Ghali. "Smart green charging scheme of centralized electric vehicle stations." International Journal of Green Energy (2021): 1-9.

https://doi.org/10.1080/15435075.2021.1947822

[44] Makeen, Peter, Hani Ghali, and Saim Memon. "Controllable Electric Vehicle Fast Charging Approach Based on Multi-Stage Charging Current Methodology." In 2020 IEEE International Conference on Power and Energy (PECon), pp. 398-403. IEEE, 2020.

https://doi.org/10.1109/PECon48942.2020.9314471

[45] Al-Ashwal, Najib T., and Ahmad Sanusi Hassan. "The Impact Of Daylighting-Artificiel Lighting Integration on Building Occupant's Health and Performance." International Journal Transaction Journal of Engineering Management \& Applied Sciences \& Technologies 9 (2018): 97-105. 
[46] Memon, Saim. "Analysing the potential of retrofitting ultra-low heat loss triple vacuum glazed windows to an existing UK solid wall dwelling." International Journal of Renewable Energy Development (IJRED) 3, no. 3 (2014): 161-174.

https://doi.org/10.14710/ijred.3.3.161-174

[47] Memon, Saim. "Design, development and thermal performance analysis of ultra-low heat loss triple vacuum glazing." In Solar World Congress 2017-Innovation for the 100\% renewable energy transformation. Abu Dhabi. (2017) ISBN 978-3-981 465 9-7-6.

https://doi.org/10.18086/swc.2017.15.04

[48] Memon, Saim. "Investigating energy saving performance interdependencies with retrofit triple vacuum glazing for use in UK dwelling with solid walls, Sustainable Development on Building and Environment." In Sustainable Development on Building and Environment: Proceedings of the 7th International Conference, 2015. ISBN-13: 9780993120701.

[49] Memon, Saim, and Philip C. Eames. "Heat load and solar gain prediction for solid wall dwellings retrofitted with triple vacuum glazing for selected window to wall area ratios." In World Renewable Energy Forum, WREF 2012, vol. 6, pp. 4636-4643. ASES, 2012. ISBN: 9781622760923

[50] CIBSE Guide A, 7th eds. 2006. Environmental Design, The Chartered Institution of Building Services Engineers, London.

[51] BS 10077-1. 2006. Thermal performance of windows, doors and shutters-calculation of thermal transmittance Part 1 General.

[52] NCM, UK. "National Calculation Methodology (NCM) modelling guide." (2014).

[53] Memon, Saim, and Philip C. Eames. "Heat load and solar gain prediction for solid wall dwellings retrofitted with triple vacuum glazing for selected window to wall area ratios." In World Renewable Energy Forum, WREF 2012, vol. 6, pp. 4636-4643. ASES, 2012. ISBN: 9781622760923

[54] Memon, Saim. 2021. "The Scope of Advanced Smart Vacuum Insulation Technologies for Net-Zero Energy Buildings", Sustainable Energy Development and Innovation, WREC 2020. Springer Nature, https://doi.org/10.1007/978-3-030-76221-6

[55] Zhang, Shanwen, Min Kong, Saim Memon, Hong Miao, Yanjun Zhang, and Sixing Liu. "Thermal Analysis of a New Neutron Shielding Vacuum Multiple Glass." Sustainability 12, no. 8 (2020): 3083.

https://doi.org/10.3390/su12083083

[56] Miao, Hong, Lingcong Zhang, Sixing Liu, Shanwen Zhang, Saim Memon, and Bi Zhu. "Laser Sealing for Vacuum Plate Glass with PbO-TiO2-SiO2-RxOy Solder." Sustainability 12, no. 8 (2020): 3118.

https://doi.org/10.3390/su12083118

[57] Phillips, Derek. Lighting modern buildings. Routledge, 2013.

[58] The SLL Code for Lighting, Society of Light and Lighting, 2012.

[59] BS EN 12464-1: Light and lighting - Lighting of work places, British Standards Institute, 2011.

[60] Lighting Guide 7: Office lighting, Society of Light and Lighting, 2015.

[61] Kim, Hyemi, Kyung-soon Park, Hwan-yong Kim, and Young-hak Song. "Study on variation of internal heat gain in office buildings by chronology." Energies 11, no. 4 (2018): 1013.

https://doi.org/10.3390/en11041013

[62] Ahn, Byung-Lip, Cheol-Yong Jang, Seung-Bok Leigh, Seunghwan Yoo, and Hakgeun Jeong. "Effect of LED lighting on the cooling and heating loads in office buildings." Applied Energy 113 (2014): 1484-1489.

https://doi.org/10.1016/j.apenergy.2013.08.050 